\title{
Review of vapor to liquid homogeneous nucleation experiments from 1968 to 1992
}

Richard H. Heist

Fairfield University, rheist@fairfield.edu

Honghai He

Follow this and additional works at: https://digitalcommons.fairfield.edu/engineering-facultypubs Copyright 1994 the Authors, published by AIP

The final publisher PDF has been archived here with permission from the copyright holder. https://aip.scitation.org/doi/abs/10.1063/1.555951

\section{Repository Citation}

Heist, Richard H. and He, Honghai, "Review of vapor to liquid homogeneous nucleation experiments from 1968 to 1992" (1994). Engineering Faculty Publications. 166.

https://digitalcommons.fairfield.edu/engineering-facultypubs/166

\section{Published Citation}

Heist, R. H., \& He, H. (1994). Review of vapor to liquid homogeneous nucleation experiments from 1968 to 1992. Journal of Physical and Chemical Reference Data, 23(5), 781-805. doi:10.1063/1.555951.

This item has been accepted for inclusion in DigitalCommons@Fairfield by an authorized administrator of DigitalCommons@Fairfield. It is brought to you by DigitalCommons@Fairfield with permission from the rightsholder(s) and is protected by copyright and/or related rights. You are free to use this item in any way that is permitted by the copyright and related rights legislation that applies to your use. For other uses, you need to obtain permission from the rights-holder(s) directly, unless additional rights are indicated by a Creative Commons license in the record and/or on the work itself. For more information, please contact digitalcommons@fairfield.edu. 
Review of Vapor to Liquid Homogeneous Nucleation Experiments from 1968 to 1992

Richard H. Heist, and Honghai He

Citation: Journal of Physical and Chemical Reference Data 23, 781 (1994); doi: 10.1063/1.555951

View online: https://doi.org/10.1063/1.555951

View Table of Contents: http://aip.scitation.org/toc/jpr/23/5

Published by the American Institute of Physics 


\title{
Review of Vapor to Liquid Homogeneous Nucleation Experiments From 1968 to 1992
}

\author{
Richard H. Heist and Honghai He \\ Department of Chemical Engineering, University of Rochester, Rochester, NY 14627-0166
}

Received December 1993; revised manuscript received July 1994

\begin{abstract}
A comprehensive review of the vapor to liquid homogeneous nucleation experiment literature from 1968 to 1992 is presented. The review identifies and presents in tabular format experimental nucleation data dealing specifically with: (1) critical supersaturation measurements in both unary and binary systems; (2) nucleation rate measurements in both unary and binary systems; (3) photoinduced nucleation experiments; and, (4) ion-induced nucleation experiments. The data tables identify the substance under investigation; the experimental method used in each investigation; the background gas and, when available, the pressure range of the background gas used in each investigation; a brief summary of the key results of each investigation; and literature references where more detailed information concerning each investigation can be found. The review contains a brief description of the operation of the experimental devices referenced in the tables. The review also contains an assessment of the_various experimental devices currently capable of quantitative nucleation rate measurements.
\end{abstract}

Key words: binary nucleation; critical supersaturation; homogeneous nucleation; ion-induced nucleation; nucleation; nucleation rate; photoinduced nucleation; vapor-to-liquid nucleation.

\section{Contents}

1. Introduction

2. Description of the Review

..............

3. Structure and Interpretation of the Review......

4. Experimental Devices ............... 784

4.1. Thermal Diffusion Cloud Chamber

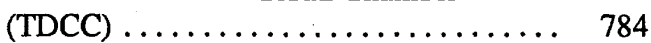

4.2. Expansion Cloud Chamber (ECC) ...... 784

4.3. Supersonic Nozzle (SN) . . . . . . . . . 784

4.4. Shock Tube (ST) . . . . . . . . . . . . . 785

4.5. Gas-Flow Diffusion Chamber (GFDC) ... 785

4.6. Continuous Flow Mixer (CFM) . . . . . . 785

4.7. Flow Reactor (FR) . . . . . . . . . 785

4.8. Gas Mixing Reaction Chamber (GMRC). . 785

4.9. Kust Apparatus (KUST) . . . . . . . . . . 785

4.10. Particle Size Magnifier (PSM) . . . . . . 786

4.11. Laminar Coaxial Jet (LCJ) . . . . . . . . 786

4.14. Laminar Flow Aerosol Generator (LFAG). 786

4.13. Turbulent Gas Mixing Chamber (TGMC) . 786

4.14. Aging Chamber (AC) ........... 786

4.15. Furnace Apparatus (FA) . . . . . . . 786

4.16. Tank Apparatus (TA) ............ 786

5. The Quantitative Measurement of Nucleation

Rate .......................... 787

6. A Few General Observations . . . . . . . . 788

7. Acknowledgment................... 803

7. References ...................... 803

(C)1995 by the U.S. Secretary of Commerce on behalf of the United States. This copyright is assigned to the American Institute of Physics and the American Chemical Society.

Reprints available from ACS; see Reprints List at back of issue.

\section{List of Tables}

1. Unary system critical supersaturation ratio ...... 789

2. Unary system nucleation rate measurement..... . 794

3. Binary system nucleation measurements ....... 797

4. Photoinduced and ion-induced nucleation experiments

\section{Introduction}

Nucleation is the process by which the first microscopic fragments of a new phase are formed. If the nucleation process involves a pre-existing surface, it is termed heterogeneous nucleation; if not, it is termed homogeneous. Nucleation, either as a heterogeneous or as a homogeneous process, is an important and commonplace phenomenon. It is an integral part of phase transitions. The formation of rain and snow, the boiling of liquids, the formation of crystals, and smog formation are but a few examples of commonly occurring phenomena involving nucleation.

Nucleation plays an important role in technology. For example, it is a key step in the manufacture of high-quality powders such as alumina and pure silicon. It is involved in the formation of small clusters, metallic and non-metallic, many of which have been found to have novel chemical and physical properties and may have important applications in catalysis and materials science. It is used for the controlled production of aerosols and ultrafine particles for applications in materials science and medicine. Finally, the control of nucleation in devices such as turbines, rocket and jet engines, wind tunnels, and combustion processes is key to achieving efficient, ecologically sound operation. 
Paralleling the recognized importance of nucleation, the literature describing experimental studies of nucleation has grown steadily from the early decades of this century. Over the last several decades, however, because of the growing emphasis on technological and scientific applications involving nucleation, this literature has increased markedly reflecting the growing research emphasis. The tools available for nucleation research have also changed markedly. Where there were once only two or three experimental devices used in nucleation research, now there are more than twenty (Table 5). Where only the onset of nucleation (e.g., critical supersaturation) was routinely measured, now the nucleation rate itself is obtained. For nearly twenty years following the seminal work on binary nucleation by Reiss ${ }^{1}$ virtually no experimental binary nucleation studies were reported. Now, there is a rather extensive literature on nucleation in binary systems. Finally, photoinduced nucleation, an important and still largely misunderstood phenomena, has only been extensively studied only over the last fifteen or so years. These examples serve to illustrate the recent, rapid growth of nucleation research and the nucleation literature. They also serve to point out the importance of reviewing and organizing this recent literature to aid those directly involved in nucleation research, as well as those individuals interested in utilizing nucleation for other applications.

The last major review of the nucleation experiment literature was published by Pound in $1972^{2}$. Smaller summaries of experimental methods ${ }^{3}$ and selected data ${ }^{4,5 a}$ have appeared in the literature from time to time, but a comprehensive review of the nucleation experiment literature covering the period from 1968 to 1992 does not exist.

The review by Pound covers the nucleation literature up to about 1968. It covers experimental investigations of vapor to liquid nucleation. It presents a summary of critical supersaturation data from single component systems. It also reviews ion-induced nucleation results obtained from single component systems. There is only one reference to nucleation in a binary system. There are few reports of nucleation rate measurements in the pre-1960's literature due to the fact that, since nucleation rate is such a sensitive function of both supersaturation and temperature, quantitative measurements are difficult. Reports of these kinds of measurements have only recently found their way into the nucleation literature.

The purpose of this paper is to present a comprehensive review of the nucleation literature dealing with experimental measurements of vapor to liquid nucleation. Although much has been done contributing to our theoretical understanding of the nucleation process over the last forty or so years, we shall not be concerned with these theoretical descriptions in this paper. Further, since the amount of experimental data in the literature is large and since the manner in which it is presented varies significantly, we shall present, in tabular form, a condensed summary of the experimental data obtained in each investigation along with the conditions under which the data were obtained and the appropriate literature references. We shall not present in this review a complete reporting of all the experimental results of each investigation.

Our primary objective in preparing this review is to provide a current resource enabling interested individuals to learn quickly: (1) what vapor to liquid nucleation experiments have been done; (2) what substances have been investigated; (3) what experimental tools have been used; (4) what type of experimental data has been generated over what ranges of conditions; and, (5) where to find detailed information about the specific nucleation experiments.

\section{Description of the Review}

This review focuses on experimental measurements of vapor to liquid nucleation. Our intent is to review that scientific literature from 1968 to 1992 which deals with: (1) critical supersaturation measurements in both unary and binary systems; (2) nucleation rate measurements in both unary and binary systems; (3) photoinduced nucleation experiments; and, (4) ion-induced nucleation experiments. Our primary source of information was the Chemical Abstracts Subject Index. This source was augmented by a computer-aided search of the Science Index and the Engineering Index. While we rather thoroughly covered the major journal sources, we also attempted to include information from published Conference Proceedings and Technical Reports from various sources but these are undoubtedly less complete.

In our review we include critical supersaturation measurements (or, more generally, the conditions accompanying the onset of nucleation) for unary and binary systems. This in itself is significant since it will be the first time a comprehensive review of binary nucleation has appeared in the literature. We expand the review by including data from nucleation rate experiments in both unary and binary systems. This is the first time a comprehensive review of nucleation rate data has appeared in the literature. We also include a detailed review of the photoinduced nucleation and ion-induced nucleation literature.

Photoinduced nucleation has only relatively recently come to the forefront of nucleation research. The potential for application in scientific and technologically important areas such as materials science and environmental science underscores the importance of reviewing the research effort to date. This paper represents the first time this literature has been systematically reviewed.

\section{Structure and Interpretation of the Review}

The body of the review is presented in tabular form. There are four separate tables devoted to the four subject areas:

Table 1: Unary Systems - Critical Supersaturation Measurements;

Table 2: Unary Systems - Nucleation Rate Measurements; Table 3: Binary Systems - Nucleation Measurements; and,

Table 4: Photoinduced and Ion-Induced Nucleation Measurements.

There are 60 different substances listed in Table 1, 24 different substances listed in Table 2, 24 different binary systems listed in Table 3, and 23 different substances listed in Table 4. In Table 4 , the first part (to the double line) is devoted to photoinduced nucleation and the second part to ion-induced nucleation. 
Each table is constructed in a similar fashion. The first column in each table is titled "Substance." In Tables 1-3, the entries in this column are organized alphabetically by nucleating substance(s). In the first part of Table 4, the material believed (by the cited authors) to be the photonucleator or the substance(s) believed to be acted upon by the light (and, possibly, other materials) to generate the actual nucleating material or produce the observed nucleation, is listed in this first column. For example, an entry in column one in the first part of Table 4 of the form "carbon disulfide" means that it is believed (by the cited authors) that carbon disulfide utilizes the excitation energy in some fashion and thus participates in the photoinduced nucleation process (there is usually a model of this process proposed by the cited authors). In the second part of Table 4, the entry in column one represents the substance which is believed to nucleate or participate in the nucleation (in some cases with other substances present in the experiment) which arises due to the presence of ions.

The second column in each table is titled "Experiment method" and contains an acronym which identifies the type of experiment device or instrument utilized in obtaining the nucleation data reviewed in the table. The acronyms used in the tables are defined in Table 5 and appropriate references are also provided there.

The third column in Tables 1-3 is titled "Background Gas:pressure" and identifies the background (or carrier) gas used in the investigation and the pressure or range of pressures employed (if provided in the reference) using the same units as given in the reference. For example, an entry in the third column of the form "He:693-1008 Torr' means that the background (or carrier) gas used in this particular investigation was helium and the reported range of pressures employed was 693 Torr to 1008 Torr. An entry in column three of the form "Ar" means that argon was used as the background (or carrier) gas and no pressure range was reported. Finally, an entry of the form "- " means the authors reported neither the nature of the background (or carrier) gas nor the pressure used in the investigation. In Table 4 , the third column is titled "'Background Gas:pressure (Host Liquid)." In addition to the background (or carrier) gas and the pressure or pressure range information, the host liquid (when applicable) which was used for the photoinduced nucleation investigation is also identified.

In each table, the fourth column is titled "Results" and contains a brief summary of the experimental findings reported in the investigation. Entries include the measured (or range of measured) critical supersaturations or the range of conditions which accompany the onset of nucleation; the measured nucleation rate (or range of nucleation rates) or measured particle number counts; the measured nucleation delay (induction) and decay times associated with the respective appearance or disappearance of nucleation; the operating temperature or range of temperatures over which nucleation measurements were made; the compositions, partial pressures, concentrations, and activities of the various species involved in the investigations; information about the presence of an activating or inhibiting species; excitation wavelengths and irradiation power ranges; and, the nature, charge, and concentration of ions used and an identification of those ion types which were more effective at inducing nucleation.

It will be helpful to review several examples of entries taken from column four and illustrate how those entries are to be interpreted. An entry in the fourth column of the tables of the form " $0.5<\log \left(S_{\text {cr }}\right)<1.0$ for $0.5<T_{\mathrm{r}}<0.55$ " means critical supersaturation data obtained using the experimental device or method identified in column two for the substance identified in column one were reported in the range of $\log _{10}\left(S_{\mathrm{cr}}\right)=0.5$ to 1.0 over the reduced temperature range of 0.5 to 0.55 . An entry in column four of the form " $0.006<$ $P P(x)<0.05 \mathrm{~atm}, 190<T<230 \mathrm{~K}$ at ONC' means the onset of nucleation or condensation was observed for the nucleating substance under investigation (identified in column 1) over a range of partial pressures for species " $x$ " of 0.006 to 0.05 atm for a temperature range of $190 \mathrm{~K}$ to $230 \mathrm{~K}$. An entry of the form " $10<\mathrm{S}_{\mathrm{cr}}<70,215 \mathrm{~K}<T<270 \mathrm{~K}, 1 \mathrm{e}+2<\mathrm{J}<1 \mathrm{e}+5$ drops $/ \mathrm{cm}^{3} \mathrm{~s}$ " means critical supersaturations in the range of 10 to 70 were measured for temperatures ranging from $215 \mathrm{~K}$ to $270 \mathrm{~K}$ and the nucleation rate observed at the onset of nucleation was in the range of $10^{2}$ to $10^{5} \mathrm{drops} / \mathrm{cm}^{3} \mathrm{~s}$. An entry of the form " $6.1 \mathrm{e}+5<J<2 \mathrm{e}+9$ drops $/ \mathrm{cm}^{3} \mathrm{~s}, 4.39<S<$ $14.45,-15<T_{\mathrm{i}}<45^{\circ} \mathrm{C}$ " means nucleation rates were measured in the range of $6.1 \times 10^{5}$ to $2.0 \times 10^{9} \mathrm{drops} / \mathrm{cm}^{3} \mathrm{~s}$ over a range of supersaturations from 4.39 to 14.45 and a range of initial temperatures from $-15^{\circ} \mathrm{C}$ to $45^{\circ} \mathrm{C}$ for the experimental method employed (indicated in column two). An entry of the form " $1.4<A C(\mathrm{e})<5.85,0.78<A C(w)<11.12,220<$ $T_{\mathrm{c}}<280 \mathrm{~K}$ at ONC" means the onset of nucleation/condensation was observed for the system identified in column one over a range of activities for component $e$ (the first letter of one of the components listed in column one) of 1.4 to 5.85 and component $w$ (the first letter of the other component listed in column one) of 0.78 to 11.12 over a condensation temperature range of 220 to $280 \mathrm{~K}$. An entry of the form " $320<E W<$ $337.1,2.7<S<7.25,250 \mathrm{~K}, 2<R<90$ counts $/ 10$ s at various light intensities; $3<R<40$ counts $/ 10 \mathrm{~s}, 2.1<\log (P P(\mathrm{~cd}))<$ 2.5 Torr, $I / I_{\mathrm{o}}=0.546$ " means one set of experiments was done utilizing a range of exitation wavelengths from $320 \mathrm{~nm}$ to $337.1 \mathrm{~nm}$ with varying excitation intensity producing a photoinduced nucleation rate of 2 to 90 counts per 10 seconds when the host supersaturation ranged from 2.7 to 7.25 at a temperature of $250 \mathrm{~K}$; and a second set of experiments was reported in which the range of excitation wavelengths was the same but the intensity was fixed at 0.546 while the $\log _{10}$ of the partial pressure of the substance indicated (column one) ranged from 2.1 to 2.5 at the same temperature as the first set of experiments.

The fifth column in each table is titled "Ref." and identifies the specific reference in the bibliography from which the information concerning that particular entry in the table was obtained. This column is, perhaps, the most important since, due to obvious limitations, only an abbreviated portion of the data in a particular reference can be reproduced in any of these tables.

Each table is provided with a Legend (located at the bottom of the table) which identifies abbreviations and conventions used in that specific table. It should be noted that although a substance may be included in only one table, some results in that table may apply to other tables. For example, data corre- 
sponding to a nucleation rate of $1 \mathrm{drop} / \mathrm{cm}^{3} \mathrm{~s}$ listed in the nucleation rate compilation (Table 2) would also apply to the critical supersaturation compilation in Table 1 for that same species. Similarly, critical supersaturation data given in the binary nucleation table for either component when the respective activities for either component are zero will also apply to the unary critical supersaturation data listed in Table 1.

Finally, the entries in Table 5 identify the acronym for the experimental method referred to in column two of Tables 1-4. It also provides representative references to literature sources which describe, in detail, the operation of that particular device.

\section{Experimental Devices}

While it is not our intent to provide detailed descriptions of all the various devices utilized by nucleation investigators, it will be helpful to include short descriptions of basic operational characteristics of these devices to allow the reader some assessment of the applicability of a particular technique. We include appropriate references in Table 5 for all the devices discussed in this review. In describing the various nucleation devices, we attempt to use, where appropriate, the same terminology as that given in the source papers.

\subsection{Thermal Diffusion Cloud Chamber (TDCC)}

The thermal diffusion cloud chamber can be operated in either an upward or a downward mode. It consists of two parallel metal plates of cylindrical geometry separated by an optically transparent cylindrical ring. The region between the two plates, bounded by the inside of the transparent ring, forms the working region of the chamber. The working fluid (substance of interest) is introduced as a shallow pool on the lower plate in the upward mode (as a moist pad or porous plate on the upper plate in the downward mode) and the chamber is filled with a stagnant, background gas. The lower (upper) plate is heated and the upper (lower) plate is cooled for the upward (downward) mode of operation.

Imposing a temperature difference between the two plates results in temperature, mole fraction, and supersaturation profiles between the two plates. These profiles are obtained by solution of the appropriate mass and energy balance equations subject to an appropriate equation of state for the vapor/background gas mixture.

The diffusion cloud chamber is a steady state, self-cleaning device. When the temperature difference between the two plates and the total pressure are such that the supersaturation in the chamber is sufficiently large, nucleated droplets are observed to form (by light scattering) in the upper (lower) portion of the chamber for the upward (downward) mode of operation. Onset of nucleation (critical supersaturation) and nucleation rate measurements can be made by light scattering techniques and particle counting methods.

\subsection{Expansion Cloud Chamber (ECC)}

There are several types of expansion cloud chambers, but they all rely upon rapid, adiabatic expansions to produce the desired degree of supersaturation and subsequent nucleation. Essentially, an expansion cloud chamber can be visualized as a cylinder/piston-like structure containing the vapor of interest and a background gas in the region above a cylinder and bounded by the piston walls. Initially, the vapor/gas mixture is at the temperature of the piston walls and may or may not be saturated. Following an expansion, caused by the rapid (partial) withdrawal of the piston, the pressure of the vapor/ gas mixture decreases somewhat while the temperature (away from the walls of the cylinder) decreases significantly due to adiabatic cooling. During this period (the sensitive time), the vapor is supersaturated and nucleation can occur. Normally, shortly after the adiabatic expansion is complete a small recompression pulse is issued to stop further nucleation and allow for growth of the nucleated clusters. The length of the sensitive time is of the order of milliseconds.

Expansion cloud chambers are capable of generating large supersaturations. These chambers are not self-cleaning, and they require repeated expansions to cleanse the vapor/gas mixture of heterogeneous nucleation sites. The temperature and supersaturation conditions in the chamber are determined by using the thermodynamic relations for adiabatic cooling and often assuming ideal gas behavior.

\subsection{Supersonic Nozzle (SN)}

The supersonic nozzle relies upon adiabatic expansion of a gas or a vapor/gas mixture flowing through a nozzle of some sort (e.g. converging/diverging, converging-straight). The gas or vapor/gas mixture is first prepared and stored in a supply tank. One or more plenum chambers are often used to insure proper mixing, temperature, and pressure conditions of the gas or vapor/gas mixture prior to flow through the nozzle. The gas or vapor/gas mixture flow is undersaturated prior to and slightly after entering the nozzle region. As the flow continues into the nozzle, the flow becomes saturated and then supersaturated. Nucleation of embryos followed by condensational growth occurs as the flow passes out of the throat region of the nozzle. As condensational growth occurs, the latent heat of condensation acts to raise the local pressure. Pressure sensors record this pressure increase and allow for detection of the location of condensation onset.

The well-known flow characteristics associated with this type of device permit the reliable computation of the density, pressure, and temperature gradients established in the nozzlc. The temperature associated with the onset of condensation can be calculated. The rapid flow conditions make it possible that heterogeneous nucleation does not contribute significantly to the observed nucleation. The onset of nucleation is usually associated with the onset of the pressure pulse; and, if the latent heat of condensation is known and the pressure is measured carefully, an estimate of the amount of condensed phase can be made. Typical cooling rates associated with

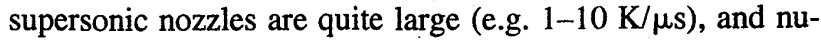
cleation rates are also large. Particle concentrations (after significant condensational growth) can be estimated with light scattering techniques. 


\subsection{Shock Tube (ST)}

Essentially, the shock tube consists of two sections, the driver and the driven sections, separated by a diaphragm. When the diaphragm is ruptured (as rapidly as possible), the higher pressure gas in the driver section sets up a nearly one dimensional, unsteady flow and a shock wave traveling to the driven section. At the same time an expansion wave travels back into the driver section followed by an expansion fan that sets the gas initially at rest in the driver section in motion toward the driven section. The subsequent cooling of the rapidly expanding gas in the driver section is what is commonly used for nucleation studies. A small amount of condensable vapor is added to the driver section prior to the expansion and the formation of particulates during the expansion is monitored using light scattering techniques.

There are several variations of the basic shock tube. The first is the cryogenic shock tube in which the driver section is maintained in a liquid nitrogen bath. This approach lends itself to studies of the condensation of incrt gases (c.g. Ar). Another variation is the Ludwieg Tube. The essential design difference in this case is the presence of a supersonic nozzle just upstream of the diaphragm between the driver and driven sections. After the diaphragm is broken, a shock wave travels into the driven section and the head of the expansion wave travels back into the driver section through the nozzle. Eventually stable conditions of supersonic flow are achieved in the nozzle and the expansion wave is reflected back and forth a number of times between the end of the driver section and the nozzle. A primary advantage of the Ludwieg Tube is the ability to produce steady supersonic flow of short duration without pressure regulators or valves. The Ludwieg Tube has also been used in the cryogenic mode.

\subsection{Gas-Flow Diffusion Chamber (GFDC)}

The GFDC has generally been used for homogeneous nucleation studies. Typically, the GFDC has two major components: a saturation unit and a mixing unit. During steady state operation, a heated, inert carrier gas flows through the saturation unit and is saturated with the condensable vapor of interest. This flowing (usually laminar) gas/vapor mixture is often referred to as the core. Upon exiting the saturator, the core is enveloped by a cooler flow of dry carrier gas, often referred to as the sheath. This coaxial flow of the core and surrounding sheath then enters the mixing unit. The wall of the mixing unit is maintained at the sheath temperature. The ensuing energy and mass transfer from the core to the sheath region results in supersaturation and nucleation. If the core and sheath streams are free from particulates, homogeneous nucleation is observed. Detection of the nucleation is done optically.

\subsection{Continuous Flow Mixer (CFM)}

The CFM has typically been used for binary nucleation studies and for ion-induced nucleation investigations. Essentially, it consists of a saturation and mixing section and a nucleation and growth section. In binary nucleation investigations, a stream of inert carrier gas is split into three streams.
Each of two of the three are saturated with one of the vapors of interest while the third is kept dry. Combining the three streams in the mixing section produces the desired flow with the composition of interest. The mixture then passes into the nucleation and growth tube where the residence time is sufficently long for the particles to develop. The effluent stream can then be sampled to determine quantities such as the number concentration and the particle size distribution.

For ion-induced nucleation investigations, a stream of high purity carrier gas is split into two streams. One stream passes through a water saturator and then through an ion generator. A portion of this stream is removed and passed through an ion counter. The second stream is passed through a temperature controlled saturation unit containing the nucleating substance of interest. The two streams are then combined in a turbulent flow mixing unit. From the mixing unit the flow passes through an expansion nozzle where it is adiabatically cooled. The flow then passes through a nucleation tube where nucleation and growth occur. The particle laden flow is then samplcd optically (c.g. light scattering) to determine the particle count.

\subsection{Flow Reactor (FR)}

The FR has typically been used for ion-induced nucleation studies. Essentially, it consists of gas flow controls, a mixing section and a flow reaction unit. During steady state operation, a filtered, inert carrier gas stream containing a condensable vapor $\left(\right.$ e.g. $\left.\mathrm{H}_{2} \mathrm{O}\right)$ is combined in the mixing unit with the reactants of interest (e.g. $\mathrm{SO}_{2}$ ). The flow streams are all individually controlled. The laminar flow from the mixer passes through the flow reactor where it is irradiated with radiation (e.g. X-rays). The effluent from the reactor is then analyzed (e.g. particle number concentration, particle size distribution, etc.).

\subsection{Gas Mixing Reaction Chamber (GMRC)}

The GMRC has been used for reaction - nucleation studies and for ion-induced nucleation investigations. It consists of a saturation section, a mixing section and a reactor section. Initially, a dry, filtered carrier gas stream is humidified. This stream is then split into three. To one is added the first reactant (e.g. $\mathrm{HCl}$ ); to the next is added the second reactant (e.g. $\mathrm{NH}_{3}$ ); while the third stream remains the moist carrier. The three streams are recombined in the reaction chamber where reaction and nucleation occur. The effluent is sampled to monitor the nucleated particles (e.g. particle number concentration). An ion source has alșo been built into the entrance to the reaction chamber to permit ion-induced nucleation studies.

\subsection{Kust Apparatus (KUST)}

The KUST apparatus has been used for homogeneous and heterogeneous nucleation studies. Basically, the apparatus consists of a saturation unit and a mixing and nucleation unit. During operation, a filtered stream of inert carrier gas passes through a heated, packed column impregnated with the nucle- 
ating material. This warm, moist flow stream then enters the mixing unit where it is tubulently mixed with a second cooler, dry flow of carrier gas. This second stream may be particle free for homogeneous nucleation. investigations, or it may contain condensation centers for heterogeneous nucleation studies. The forced, turbulent mixing of the two streams results in supersaturation and subsequent nucleation as the combined stream flow from the mixing unit. A second KUST apparatus is sometimes placed in series with the first and used to grow or coagulate the particles nucleated in the first apparatus. The particle number count is obtained directly or inferred from light scattering data. An ultramicroscope is used to obtain detailed information about the individual droplets.

\subsection{Particle Size Magnifier (PSM)}

The PSM is used to investigate both homogeneous and heterogeneous nucleation. During operation, a dry, filtered carrier gas stream is split into two. One stream passes through a heated saturator (e.g. packed column impregnated with the nucleating substance of interest) and then is recombined with the other (cool) stream in a turbulent flow mixing section. The resulting mixture immediately enters a reheater section where the stream is held at a constant temperature during the nucleation and growth process. The stream containing the nucleated particulates is then sampled by a variety of techniques to determine the particle number concentration.

\subsection{Laminar Coaxial Jet (LCJ)}

The LCJ consists primarily of a vaporizer/humidifier section and a cylindrical mixing and nucleation chamber. A dry, filtered carrier gas flow is humidified with the nucleating substance of interest either by volatilizing a known amount of liquid sample into the flow or by passing the flow through a packed, saturated column. The flow from the humidifier unit then issues from a nozzle as a laminar flow jet into the mixing cylinder. A coaxial flow of filtered, cool air surrounds the jet along the entire length of the mixing cylinder. The jet cools during passage through the mixing cylinder, and the resulting supersaturation gives rise to nucleation.

\subsection{Laminar Flow Aerosol Generator (LFAG)}

The LFAG has been used for both homogeneous and heterogeneous nucleation investigations. In this device dry, filtered carrier gas is passed through a packed saturator column (e.g. silica gel) impregnated with the working fluid of interest. The resulting laminar flow is heated to a uniform temperature and passed through a cooling zone which supersaturates the vapor and initiates nucleation. A variation of this device allows for addition of condensation nuclei to the stream containing the moist vapor prior to entering the heating zone in order to study heterogeneous nucleation. The flow from the cooling zone which contains the particles is monitored (usually optically) to determine number concentration and particle size distribution.

\subsection{Turbulent Gas Mixing Chamber (TGMC)}

The TGMC has been used primarily for binary nucleation investigations involving acid-water systems. Both heterogeneous and homogeneous nucleation investigations have been carried out. Essentially, the device consists of a tubular glass furnace, a mixing chamber and a nucleation and growth chamber. A liquid solution (e.g. $\mathrm{H}_{2} \mathrm{SO}_{4}-\mathrm{H}_{2} \mathrm{O}$ ) is injected into the furnace and vaporized. The resulting hot vapor is filtered and passed into a mixing chamber where it is turbulently mixed with cooler (ambient) air. This mixture flows immediately into the nucleation chamber where cooling continues and nucleation and growth occur. The particulate-laden flow is then analyzed using a variety of particle measurement instrumentation.

\subsection{Aging Chamber (AC)}

The AC has generally been used for ion-induced nucleation studies and typically consists of three major components: a saturator unit, an ionization unit and an aging or growth unit. During steady state operation, a dry inert carrier gas is cleaned and filtered and then split into two streams. One stream passes through a saturator consisting of a collection of tubes halffilled with water. The two streams are then recombined to produce the desired humidification. To this humidified gas is added a substance of interest (e.g. $\mathrm{SO}_{2}$ ) along with any other desired reactant (e.g. $\mathrm{NH}_{3}$ ). This mixture passes through an ionization chamber containing one of a variety of ion sources (e.g. $\alpha$-emitter, corona, spray ions). From the ionization chamber, the mixture flows into an aging chamber which provides residences times for growth typically of the order of ten seconds. The flow then passes to a condensation nuclei counter.

\subsection{Furnace Apparatus (FA)}

The FA is typically used for nucleation of refractory materials. Essentially, it consists of a resistively heated crucible containing the material of interest (e.g. SiO) and a furnace which surrounds the crucible to control the ambient temperature. During operation, the crucible is heated to produce the condensable vapor. The temperature of the furnace is controlled to produced a difference in the ambient temperature and the crucible temperature such that nucleation of the refractory vapor occurs above the crucible. The nucleation is detected optically through a collection of long, cylindrical alumina tubes positioned through the furnace walls. The pressure in the furnace is typically maintained in the low-torr range.

\subsection{Tank Apparatus (TA)}

The TA has been primarily used for nucleation studies involving water and sulfuric acid. Essentially, it is composed of a sample preparation and dilution unit and a stainless steel tank. The tank is first evacuated and water vapor is introduced. It is then brought up to atmospheric pressure using an $80 \% / 20 \%$ mixture of $\mathrm{N}_{2}$ and $\mathrm{O}_{2}$, respectively. $\mathrm{SO}_{3}$ from a 
$\mathrm{SO}_{3} / \mathrm{H}_{2} \mathrm{SO}_{4}$ mixture is metered into the dilution unit and then into the tank. After a period of time, a portion of the contents of the tank are removed and analyzed using a condensation nuclei counter.

\section{The Quantitative Measurement of Nucleation Rate}

Prior to the late 1960's, vapor to liquid nucleation investigations focused primarily on determining critical supersaturations of substances at various temperatures ${ }^{2}$. The strong dependence of nucleation rate on supersaturation made the observation of an onset of nucleation along with the corre-" sponding definition of a "critical" supersaturation a somewhat meaningful (and useful) quantity. However, this strong dependence also made it exceedingly difficult to make quantitative measurements of the actual nucleation rate at various supersaturations and temperatures. In fact, one investigator remarked in 1969 " A quantitative test of nucleation theory by means of published cloud chamber data is not feasible.",5b Although this view was understandable (and reasonably correct) at the time, it is no longer true. It is now possible, utilizing devices just described, to make quantitative nucleation rate measurements as functions of temperature and supersaturation over wide ranges of nucleation rates that can be used for quantitative tests of nucleation theories (over accessible ranges of temperature and pressure). The nucleation devices most commonly used for these types of nucleation measurements are the thermal diffusion cloud chamber and the expansion cloud chamber.

The thermal diffusion cloud chamber can be used for nucleation rate measurements over the range of approximately $10^{3}$ to $10^{3} \mathrm{drops} / \mathrm{cm}^{3} \mathrm{~s}$ with a resolution limited primarily by the statistical nature of the nucleation process and a reproducibility (from laboratory to laboratory) limited by the determination of the counting volume and the supersaturation and temperature conditions in the chamber. Because of the steady state nature of diffusion cloud chamber operation, the optically accessible configuration of the chamber; and the relatively small number of droplets to be counted, quantitative nucleation measurements are reasonably straightforward ${ }^{4}$. Isothermal nucleation rate measurements can routinely be made as a function of supersaturation. Critical supersaturation data is obtained naturally from the rate experiments by determining the values of the supersaturation at the various temperatures corresponding to a rate of one drop $/ \mathrm{cm}^{3} \mathrm{~s}$. Nucleation data obtained at higher rates, e.g. $>10-50 \mathrm{drops} / \mathrm{cm}^{3} \mathrm{~s}$ in the diffusion cloud chamber must be corrected for vapor depletion and latent heat effects associated with the growing, nucleated droplets since the local concentration of condensable vapor and temperature are perturbed by these effects ${ }^{4}$. The isothermal variation of nucleation rate as a function of supersaturation is a particularly useful measurement as it allows for convenient comparison with theoretical nucleation rate expressions, as well as permitting the determination of the excess number of monomers in the critical nucleus ${ }^{5 c}$.

Diffusion cloud chamber operation is possible from near triple point temperatures (a degree of supercooling is possible) to critical point temperatures and from pressures below ambient to elevated pressures (e.g. 50-100 bar). The temperature and supersaturation conditions in the chamber are determined by solution of the appropriate, one dimensional energy and mass transport equations. Considerable thermodynamic and hydrodynamic data are required to properly characterize the chamber conditions. Finally, diffusion cloud chambers are self-cleaning devices (with respect to particulates).

Expansion cloud chambers are capable of generating large nucleation rates due to short sensitive times and, in some cases, large nucleation volumes. They are capable of achieving significantly larger supersaturations than the diffusion cloud chamber. The transient nature of expansion cloud chamber operation requires somewhat more care in the measurement and analysis of the nucleation rate data ${ }^{12-14,15,48,92}$. Including the several versions of expansion chambers currently in use, accessible nucleation rates range from approximately $10^{2}$ to more than $10^{8}$ drops $/ \mathrm{cm}^{3} \mathrm{~s}$. A range which nicely complements that available with the diffusion cloud chambers. Resolution and reproducibility are roughly comparable with that of the diffusion cloud chamber. Isothermal nucleation rate measurements as a function of supersaturation are also feasible. As described above, the measurement of the isothermal variation of nucleation rate is particularly useful as it allows for convenient comparison with theoretical nucleation rate expressions, as well as providing detailed information about the excess number of monomers in the critical nucleus ${ }^{5 c}$. The nucleation rate data obtained from both the diffusion and expansion cloud chambers are generally in agreement although, in some cases, there remains disagreement.

Expansion cloud chambers normally operate at temperatures from somewhat above ambient to temperatures in the range of $200 \mathrm{~K}$ and at total pressures ranging from sub-ambient to several bar. Temperature and supersaturation conditions in the expansion chamber are determined by solving the appropriate adiabatic cooling equations utilizing an appropriate equation of state (usually ideal gas) and additional thermodynamic data. Expansion cloud chambers are not self cleaning, so that a series of consecutively increasing expansions are required to purge the chamber of pre-existing condensation centers.

As described previously in Sec. 4. Experimental Devices, there are a number of flow-type nucleation chambers that are utilized for a wide variety of nucleation investigations. Most of these devices are capable of, at least, semi-quantitative critical supersaturation measurements. This is, in large part, due to the fact that the experimentally measured onset of nucleation often corresponds to a rather large homogeneous nucleation rate. Under these conditions, a number of deleterious effects that can adversely effect nucleation rate measurements (see below) tend not to be important. Quantitative nucleation rate measurements, however, can be more problematic. For example, at lower, sustaincd nucleation rates (e.g. $10^{-2}$ to roughly $10^{2} \mathrm{drops} / \mathrm{cm}^{3} \mathrm{~s}$ ), it is often difficult to eliminate unwanted background nucleation in flowing systems. Background nucleation results from small particulates entrained in the flow and by ions. Flow systems tend not to be self cleaning, and the flow is not usually recycled so as to allow gradual removal of particulates. As a result, careful 
filtcring, application of an electric field, or other sorts of flow stream cleansing procedures are required to eliminate condensation centers whose presence would erroneously contribute to the measured nucleation rate. At higher, sustained nucleation rates (e.g. usually in excess of $10^{1}$ to $10^{2} \mathrm{drops} / \mathrm{cm}^{3} \mathrm{~s}$ ), vapor depletion and latent heat effects tend to become important. It is necessary to know accurately the temperature and concentration (supersaturation) profiles throughout the entire region where nucleation can occur in order to account for these effects, as well as relate the observed nucleation rate to appropriate experimental variables and, eventually, nucleation theory predictions. It is also important to carefully control the flow geometry of the device since small convective disturbances can promote (local) homogeneous nucleation that would erroneously contribute to the measured nucleation rate.

Supersonic nozzle and shock tube devices offer a number of important capabilities which render them important tools in nucleation research. Large cooling rates, access to low nucleation temperatures (and materials that do not condense at higher temperatures), and an ability to generate large supersaturations are several particularly useful features. In most cases, nucleated droplets are observed directly by light scattering techniques, and the pressure and temperature conditions corresponding to nucleation at a certain rate (usually large) are obtained and compared to nucleation theory predictions, as well as similar data from other laboratories. Reproducibility from laboratory to laboratory is reasonably good, and comparison with similar data obtained using expansion cloud chambers (when available) is also reasonably good. Measurement of nucleation rate as a function of temperature and supersaturation tends not to be as convenient as with the diffusion and expansion chambers and the resolution of the rate data not as detailed.

\section{A Few General Observations}

It can be argued that modern nucleation literature had it's beginnings in the 1930 's. From that time until the early 1970 's considerable progress was made in the fundamental understanding of the nucleation process. Unfortunately, the experimental complement of this fundamental progress was not keeping the same pace. Pound's review in $1968^{2}$ listed only 13 different substances for which vapor to liquid homogeneous nucleation data had been published and only one pair of substances for which binary vapor to liquid homogeneous nucleation data had been published. Furthermore, all of these data were obtained using only three different kinds of experimental devices. In addition, all of the experimental data in Pound's review represented critical supersaturation measurements - measurements of the onset of nucleation, not a single nucleation rate measurement was reported. Over the next two and one-half decades, this list of substances (involving critical supersaturation and nucleation rate investigations) has grown from 13 to 70, and the list of binary systems has grown from one to 24. The number of experimental methods being used by nucleation investigators has increased from three to more than twenty; although, of coursc, a number of thesc cxpcrimental devices are variations of other devices. Quantitative nucleation rate measurements as functions of supersaturation and temperature are now routinely made in a number of laboratories. In spite of the strong dependence of the nucleation rate on supersaturation and temperature and the accompanying difficulties of measuring very large and very small rates, detailed measurements have been made of rates ranging from less than $10^{-3} \mathrm{drops} / \mathrm{cm}^{3} \mathrm{~s}$ to greater than $10^{8} \mathrm{drops} / \mathrm{cm}^{3} \mathrm{~s}$.

Over the last ten to fifteen years there has been a great deal of interest focused on photoinduced nucleation and ion-induced nucleation. While considerable progress has been made, particularly with the experimental investigations, the fundamental, underlying mechanisms (particularly regarding photoinduced nucleation) remain unclear and much remains to be done concerning our understanding of these processes. The growing interest in applications of photoinduced nucleation to materials and materials processing adds motivation for this understanding.

It should also be remarked at this point that one of the objectives motivating a significant amount of nucleation experimental research over the last two decades was to examine predictions of alternative descriptions of the nucleation process. In particular, there has been considerable interest in examining predictions of the Lothe-Pound description vis-avis current versions of the Becker-Doering-Zeldovitch (BDZ) description. While it is not our intention to provide a detailed description of these descriptions or the related experimental investigations, it is appropriate to mention that in most every report the Lothe-Pound description provided a less satisfactory description of the experimental results than did current versions of the $\mathrm{BDZ}$ description. While this does not constitute a verification of these descriptions, it does suggest that the most current versions of the $\mathrm{BDZ}$ description arc more useful, in a practical sense, for predicting nucleation behavior.

Finally, we conclude by noting again that the literature describing experimental investigations of vapor to liquid nucleation has grown significantly over the last 25 years. In view of the growing emphasis on technological and scientific applications of nucleation, particularly in the area of materials, ultrafine particles, and separation processes, it is anticipated that this growth will not only continue but also increase. Hopefully, this continued interest will promote a corresponding increase in the level of our understanding of the fundamental processes underlying the nucleation process. 
REVIEW OF VAPOR TO LIQUID HOMOGENEOUS NUCLEATION EXPERIMENTS

TABLE 1. Unary system critical supersaturation ratio

\begin{tabular}{|c|c|c|c|c|}
\hline Substance & $\begin{array}{l}\text { Experiment } \\
\text { Method }\end{array}$ & $\begin{array}{l}\text { Background } \\
\text { Gas:pressure }\end{array}$ & Results & Ref. \\
\hline Acetone & TDCC & - & $0.5<\log \left(S_{\mathrm{cr}}\right)<1.0,0.5<T_{\mathrm{r}}<0.55$ & 106 \\
\hline $\begin{array}{l}\text { Acetic } \\
\text { acid }\end{array}$ & TDCC & $\begin{array}{l}\text { He:693-1008 Torr } \\
\mathrm{H}_{2}: 850-1188 \text { Torr }\end{array}$ & $2.5<S_{\mathrm{cr}}<5.2,280<T<340 \mathrm{~K}$ & 49 \\
\hline Acetonitrile & TDCC & He:770-1005 Torr & $2<S_{\mathrm{cr}}<8,230<T<300 \mathrm{~K}$ & 38 \\
\hline Ammonia & SN & Dry air: $1 \mathrm{~atm}$ & $\begin{array}{l}0.01<P P(a)<0.4 \mathrm{~atm}, 160<T<205 \mathrm{~K} \\
\text { varying moisture content at } \mathrm{ONC}\end{array}$ & 113 \\
\hline \multirow[t]{5}{*}{$\mathrm{Ar}$} & FJ & $\mathrm{Ar}$ & $0.1<P<10$ Torr, $10<T<50 \mathrm{~K}$ at $\mathrm{ONC}$ & 54 \\
\hline & SN & $\mathrm{Ar}$ & $1.0<P<1000 \mathrm{Torr}, 30<T<70 \mathrm{~K}$ at $\mathrm{ONC}$ & 55 \\
\hline & & He: $181-796$ Torr & $0.6<P P(\mathrm{a})<8.92 \mathrm{Torr}, 30<T<45 \mathrm{~K}$ at $\mathrm{ONC}$ & 43 \\
\hline & ST & He: $1400-3900$ Torr & $1<P P($ a $)<170$ Torr, $47<T<76 \mathrm{~K}$ at $\mathrm{ONC}$ & 147 \\
\hline & CLT & He:3.7-5 atm & $0.5<P P(a)<58$ Torr, $40<T<63 \mathrm{~K}$, at ONC & 148 \\
\hline \multirow[t]{2}{*}{ Benzene } & SN & Air: 60 psig & $0.006<P P(\mathrm{~b})<0.05 \mathrm{~atm}, 190<T<230 \mathrm{~K}$ at $\mathrm{ONC}$ & 114 \\
\hline & ST & Ar: $1055-1358$ & $\begin{array}{l}11<P P(b)<40 \text { Torr, } 21.5<S_{\mathrm{cr}}<62.6 \\
208<T<238 \mathrm{~K} \text { at ONC }\end{array}$ & 65 \\
\hline Benzophenone & TDCC $_{2}$ & He:19-225 kPa & $20<S_{\mathrm{rr}}<700.240<T<340 \mathrm{~K}$ & 127 \\
\hline Bismuth & ST & Ar & $\begin{array}{l}2<\ln \left(S_{\mathrm{cr}}\right)<11,750<T<1300 \mathrm{~K} \text { at } \mathrm{ONC} \text {; } \\
\text { start with } \mathrm{Bi}\left(\mathrm{CH}_{3}\right)_{3}\end{array}$ & 136 \\
\hline$n$-Butanol & TDCC & - & $0.5<\log \left(S_{\mathrm{ct}}\right)<1.0,0.45<T_{\mathrm{r}}<0.55$ & 106 \\
\hline \multirow[t]{4}{*}{$n$-Butylbenzene } & TDCC & $\begin{array}{l}\mathrm{N}_{2}, \mathrm{H}_{2}, \mathrm{Ne}, \mathrm{Ar}, \mathrm{He} \\
80-95 \text { Torr }\end{array}$ & $0.5<\log \left(S_{\mathrm{cr}}\right)<2.8,210<T<390 \mathrm{~K}$ & 133 \\
\hline & & He:14-1714 Torr & $1<S_{\mathrm{er}}<500,210<T<390 \mathrm{~K}$ & 7 \\
\hline & & $H_{2}: 13-1055$ Torr & $5<S_{\mathrm{er}}<220,220<T<390 \mathrm{~K}$ & 7 \\
\hline & & $\begin{array}{l}\text { Ne:6-1240 Torr } \\
\text { N2:6-1010 Torr } \\
\text { Ar:9-711 Torr }\end{array}$ & $\begin{array}{l}1<S_{\mathrm{cr}}<510,210<T<340 \mathrm{~K} \text {; } \\
\text { varying diameter-to-height ratio }\end{array}$ & 7 \\
\hline Carbon & TDCC & $\mathrm{H}_{2}, \mathrm{He}: 80-95$ Torr & $0.6<\log \left(S_{\mathrm{cr}}\right)<1.0,250<T<300 \mathrm{~K}$ & 133 \\
\hline \multirow[t]{2}{*}{ tetrachloride } & & $\begin{array}{l}\text { He:1410-2060 Torr } \\
\mathrm{H}_{2}: 1580-2090 \text { Torr }\end{array}$ & $3<S_{\mathrm{cr}}<9,250<T<300 \mathrm{~K}$ & 6 \\
\hline & ST & Ar: 1887-2092 Torr & $\begin{array}{l}11<P P(\mathrm{ct})<50 \mathrm{Torr}, 22.4<S_{\mathrm{cr}}<47.1 \text {, } \\
209<T<231 \mathrm{~K} \text { at ONC }\end{array}$ & 65 \\
\hline \multirow[t]{3}{*}{ Chloroform } & TDCC & $\mathrm{H}_{2}, \mathrm{He}: 80-95$ Torr & $0.6<\log \left(S_{\mathrm{cr}}\right)<1.3,210<T<280 \mathrm{~K}$ & 133 \\
\hline & & $\begin{array}{l}\text { He:5 12-2030 Torr } \\
\mathrm{H}_{2}: 540-2095 \text { Torr }\end{array}$ & $4<S_{\mathrm{cr}}<20,210<T<280 \mathrm{~K}$ & 6 \\
\hline & SN & Air: 60 psig & $0.007<P P(\mathrm{c})<0.06 \mathrm{~atm}, 190<T<230 \mathrm{~K}$ at $\mathrm{ONC}$ & 114 \\
\hline $\begin{array}{l}\text { Decanoic } \\
\text { acid }\end{array}$ & TDCC & He:10-410 Torr & $2<S_{\mathrm{cr}}<16,330<T<430 \mathrm{~K}$ & 128 \\
\hline $\begin{array}{l}\text { Di-2-ethyl } \\
\text { hexyl sebacate }\end{array}$ & TDCC & $\mathrm{H}_{2}, \mathrm{He}$ & $20<S_{\mathrm{cr}}<150,360<T<440 \mathrm{~K}$ & 117 \\
\hline
\end{tabular}


TABLE 1. Unary system critical supersaturation ratio - Continued

\begin{tabular}{|c|c|c|c|c|}
\hline Substance & $\begin{array}{l}\text { Experiment } \\
\text { Method }\end{array}$ & $\begin{array}{l}\text { Background } \\
\text { Gas:pressure }\end{array}$ & Results & Ref. \\
\hline $\begin{array}{l}\text { Dioctyl } \\
\text { phthalate }\end{array}$ & $\mathrm{TDCC}_{2}$ & $\begin{array}{l}\mathrm{He}: 3.5-226 \mathrm{kPa} \\
\mathrm{H}_{2}: 1.5-220 \mathrm{kPa}\end{array}$ & $10<S_{\mathrm{cr}}<300,320<T<400 \mathrm{~K}$ & 77 \\
\hline \multirow[t]{8}{*}{ Ethanol } & TDCC & He: $1050-1100$ Torr & $2.2<S_{\mathrm{cr}}<2.6,260<T<290 \mathrm{~K}$ & 99 \\
\hline & & - & $0.3<\log \left(S_{\text {cr }}\right)<0.9,0.4<T_{\mathrm{r}}<0.6$ & 106 \\
\hline & & He:0.5,1.0,1.5 MPa & $1.7<S_{\mathrm{cr}}<2.1,310<T<370 \mathrm{~K}$ & 93 \\
\hline & ST & Dry air & $2<P<10$ Torr, $220<T<250 \mathrm{~K}$ at $\mathrm{ONC}$ & 115 \\
\hline & & Ar: $1 \mathrm{~atm}$ & $\begin{array}{l}0.06<P P(\mathrm{e})<8 \mathrm{Torr}, 220<T<280 \mathrm{~K} \\
1.0 \mathrm{e}+7<J<1.0 \mathrm{e}+9 \text { at } \mathrm{ONC}\end{array}$ & 17 \\
\hline & SN & $\begin{array}{l}\text { Dry air, } \mathrm{N}_{2} \text { : } \\
625 \text { Torr }\end{array}$ & $0.1<P P(\mathrm{e})<100 \mathrm{Torr}, 200<T<300 \mathrm{~K}$ at $\mathrm{ONC}$ & 132 \\
\hline & & Air: $60 \mathrm{psig}$ & $0.008<P P(\mathrm{e})<0.03 \mathrm{~atm}, 235<T<265 \mathrm{~K}$ at $\mathrm{ONC}$ & 114 \\
\hline & ECC & Ar: $1185-1205$ & $2.2<S_{\mathrm{cr}}<2.6,250<T<270 \mathrm{~K}$ & 13 \\
\hline \multirow[t]{2}{*}{$\begin{array}{l}\text { Ethyl } \\
\text { benzene }\end{array}$} & TDCC & $\mathrm{He}$ & $\begin{array}{l}1<S_{\mathrm{cr}}<16,260<T<340 \mathrm{~K} \text {; benzoyl peroxide or } \\
\text { styrene in liquid pool as initiator }\end{array}$ & 68 \\
\hline & & He:500-1060 Torr & $4<S_{\mathrm{cr}}<16,260<T<340 \mathrm{~K}$ & 18 \\
\hline $\begin{array}{l}\text { Formic } \\
\text { acid }\end{array}$ & TDCC & He: $1160-1240$ Torr & $4<S_{\mathrm{cr}}<6,280<T<305 \mathrm{~K}$ & 9 \\
\hline \multirow[t]{4}{*}{ Freon-11 } & TDCC & $\mathrm{H}_{2}$,He:80-95 Torr & $0.5<\log \left(S_{\mathrm{cr}}\right)<1.0,200<T<250 \mathrm{~K}$ & 133 \\
\hline & & $\begin{array}{l}\text { He:1053-2044 Torr } \\
\mathrm{H}_{2}: 1190-1990 \text { Torr }\end{array}$ & $3<S_{\mathrm{cr}}<9,200<T<250 \mathrm{~K}$ & 6 \\
\hline & SN & Air: 60 psig & $0.005<P P(f)<0.02 \mathrm{~atm}, 155<T<180 \mathrm{~K}$ at $\mathrm{ONC}$ & 114 \\
\hline & ST & Ar:2041-2370 Torr & $\begin{array}{l}32<P P(f)<161 \text { Torr, } 6.7<S_{\mathrm{cr}}<8.7 \\
201<T<225.5 \mathrm{~K} \text { at } \mathrm{ONC}\end{array}$ & 65 \\
\hline $\begin{array}{l}\text { Heptanoic } \\
\text { acid }\end{array}$ & TDCC & He:27-741 Torr & $1<S_{\mathrm{cr}}<10,320<T<430 \mathrm{~K}$ & 128 \\
\hline \multirow[t]{2}{*}{$n$-Heptane } & TDCC & $\mathrm{H}_{2}: 429-1155$ Torr & $3<S_{\mathrm{cr}}<13,240<T<295 \mathrm{~K}$ & 41 \\
\hline & & $\mathrm{H}_{2}: 80-95$ Torr & $0.5<\log \left(S_{\mathrm{cr}}\right)<1.2,230<T<305 \mathrm{~K}$ & 133 \\
\hline \multirow[t]{3}{*}{$n$-Hexane } & TDCC & $\mathrm{H}_{2}: 486-1128$ Torr & $3<S_{\mathrm{cr}}<14,210<T<280 \mathrm{~K}$ & 41 \\
\hline & & He:453-619 Torr & $3<S_{\mathrm{cr}}<14,220<T<270 \mathrm{~K}$ & 41 \\
\hline & & $\mathrm{H}_{2}, \mathrm{He}: 80-95$ Torr & $0.5<\log \left(S_{\mathrm{cr}}\right)<1.2,210<T<290 \mathrm{~K}$ & 133 \\
\hline \multirow[t]{2}{*}{ Iron } & ST & $\begin{array}{l}\mathrm{Ar}, \mathrm{N}_{2} \mathrm{O} / \mathrm{Ar} \\
\mathrm{H}_{2} / \mathrm{N}_{2} \mathrm{O} / \mathrm{Ar}\end{array}$ & $\begin{array}{l}0.5<\log (C P)<1.5 \text { at ONC (avalanche), } \\
1900<T<2500 \mathrm{~K}\end{array}$ & 70 \\
\hline & & $\mathrm{Ar}$ & $\begin{array}{l}2<\ln \left(S_{\mathrm{Cr}}\right)<7,1600<T<2150 \mathrm{~K} \\
1 \mathrm{e}+5<J<\mathrm{le}+16 \text { at } \mathrm{ONC} ; 0.74 \% \mathrm{Fe}(\mathrm{CO})_{\mathrm{S}}\end{array}$ & 136 \\
\hline Iron oxide & ST & $\begin{array}{l}\mathrm{Ar}, \mathrm{N}_{2} \mathrm{O} / \mathrm{Ar} \\
\mathrm{H}_{2} / \mathrm{N}_{2} \mathrm{O} / \mathrm{Ar}\end{array}$ & $\begin{array}{l}0<\log (C P)<1.2 \text { at ONC (avalanche), } \\
1900<T<2900 \mathrm{~K}\end{array}$ & 70 \\
\hline $\begin{array}{l}\text { Iron Penta- } \\
\text { carbonyl }\end{array}$ & TDCC & He:556-917 Torr & $2<S_{\mathrm{cr}}<18,250<T<300 \mathrm{~K}$ & 29 \\
\hline
\end{tabular}


TABLE 1. Unary system critical supersaturation ratio - Continued

\begin{tabular}{|c|c|c|c|c|}
\hline Substance & $\begin{array}{l}\text { Experiment } \\
\text { Method }\end{array}$ & $\begin{array}{l}\text { Background } \\
\text { Gas:pressure }\end{array}$ & Results & Ref. \\
\hline Iron:Silicon & ST & $\begin{array}{l}\mathrm{Ar}, \mathrm{N}_{2} \mathrm{O} / \mathrm{Ar} \\
\mathrm{H}_{2} / \mathrm{N}_{2} \mathrm{O} / \mathrm{Ar}\end{array}$ & $\begin{array}{l}0<\log (C P S)<1 \text { at } \mathrm{ONC} \text { (avalanche), } \\
1550<T<2450 \mathrm{~K}\end{array}$ & 70 \\
\hline $\begin{array}{l}\text { Lead } \\
\text { tetramethyl }\end{array}$ & ST & $\mathrm{Ar}$ & $2<\ln \left(S_{\mathrm{cr}}\right)<5,950<T<1250 \mathrm{~K}$ & 136 \\
\hline l-Menthol & TDCC & He:459-642 Torr & $1<S_{\mathrm{cr}}<20,300<T<400 \mathrm{~K}$ & 25 \\
\hline \multirow[t]{2}{*}{ Mercury } & TDCC & $\mathrm{He}$ & $1<\ln \left(S_{\mathrm{cr}}\right)<15,250<T<410 \mathrm{~K}$ & 10 \\
\hline & & A light inert & $2<\log \left(S_{\mathrm{cr}}\right)<6,250<T<320 \mathrm{~K}$ & 66 \\
\hline \multirow[t]{3}{*}{ Methanol } & TDCC & & $0.2<\log \left(S_{\mathrm{cr}}\right)<0.7,0.4<T_{\mathrm{r}}<0.6$ & 106 \\
\hline & & He:1370-1586 Torr & $1.5<S_{\mathrm{cr}}<2.0,280<T<310 \mathrm{~K}$ & 23 \\
\hline & ST & Ar: 1 atm & $\begin{array}{l}0.3<P P<50 \text { Torr, } 210<T<260 \mathrm{~K} \\
J \sim 1 \mathrm{e}+8 \text { at } \mathrm{ONC}\end{array}$ & 17 \\
\hline $\begin{array}{l}\text { alpha-Methyl } \\
\text { styrene }\end{array}$ & TDCC & He:533-683 Torr & $2<S_{\mathrm{cr}}<16,260<T<350 \mathrm{~K}$ & 18 \\
\hline $\begin{array}{l}\text { Myristic } \\
\text { acid }\end{array}$ & TDCC & He:11-198 Torr & $2<S_{\mathrm{cr}}<16,350<T<450 \mathrm{~K}$ & 128 \\
\hline Naphthalene & TDCC & $\mathrm{He}: 133-201 \mathrm{kPa}$ & $3<S_{\mathrm{cr}}<7,350<T<410 \mathrm{~K}$ & 28 \\
\hline Nickel & ST & Ar & $\begin{array}{l}\text { Nucleation monitored by } A A \text { and optical } \\
\text { extinction as function of initial } \\
\text { supersaturation; nickel generated by } \\
\text { thermal decomposition of } \mathrm{Ni}(\mathrm{CO})_{4}\end{array}$ & 88 \\
\hline \multirow[t]{4}{*}{ Nitrogen } & CST & $\mathrm{He}$ & $\begin{array}{l}1<P<100 \mathrm{Torr}, 35<T<55 \mathrm{~K} \text { at } \mathrm{ONC} \text {; } \\
\text { four mixtures with } 0-50 \% \mathrm{He}\end{array}$ & 31 \\
\hline & & He:1762-3039 Torr & $45<P P(n)<230$ Torr, $50<T<70 \mathrm{~K}$ at ONC & 101 \\
\hline & FJ & $0.2-3$ bar & le $-3<P<1 \mathrm{e}+3$ Torr, $5<T<60 \mathrm{~K}$ at $\mathrm{ONC}$ & 46 \\
\hline & SN & $0.2-3$ bar & $1 \mathrm{e}-3<P<1 \mathrm{e}+3 \mathrm{Torr}, 5<T<60 \mathrm{~K}$ at $\mathrm{ONC}$ & 32 \\
\hline Nitromethane & TDCC & - & $3.5<S_{\mathrm{er}}<9.5,250<T<300 \mathrm{~K}$ & 50 \\
\hline \multirow[t]{6}{*}{$n$-Nonane } & TDCC & $\mathrm{H}_{2}: 22-461$ Torr & $\begin{array}{l}5<S_{\mathrm{cr}}<60,230<T<310 \mathrm{~K} \\
\text { varying diameter-to-height ratio }\end{array}$ & 41 \\
\hline & & He:27-1235 Torr & $\begin{array}{l}2<S_{\mathrm{cr}}<80,220<T<340 \mathrm{~K} \\
\text { varying diameter-to-height ratio }\end{array}$ & 41 \\
\hline & & Ne:28-1197 Tort & $5<S_{\mathrm{cr}}<60,235<T<325 \mathrm{~K}$ & 41 \\
\hline & & $\mathrm{H}_{2}, \mathrm{He}: 80-95$ Torr & $0.6<\log \left(S_{\mathrm{cr}}\right)<1.9,220<T<320 \mathrm{~K}$ & 133 \\
\hline & & He:293-1235 Torr & $1<S_{\mathrm{cr}}<20,260<T<330 \mathrm{~K}$ & 7 \\
\hline & ECC & Ar: 1200 Torr & $\begin{array}{l}10<S_{\mathrm{cr}}<70,215<T<270 \mathrm{~K} \\
1 \mathrm{e}+2<J<1 \mathrm{e}+5 \text { at } \mathrm{ONC}\end{array}$ & 14 \\
\hline n-Octane & TDCC & $\mathrm{H}_{2}: 133-500$ Torr & $3<S_{\mathrm{cr}}<30,230<T<295 \mathrm{~K}$ & 41 \\
\hline $\begin{array}{l}\text { Phthalic } \\
\text { Anhydride }\end{array}$ & TDCC & $\mathrm{He}: 103-131 \mathrm{kPa}$ & $2<S_{\mathrm{er}}<5,400<T<450 \mathrm{~K}$ & 28 \\
\hline$i$-Propanol & TDCC & He: $1070-1200$ & $2.0<S_{\mathrm{cr}}<3.4,260<T<310 \mathrm{~K}$ & 99 \\
\hline
\end{tabular}


TABLE 1. Unary system critical supersaturation ratio - Continued

\begin{tabular}{|c|c|c|c|c|}
\hline Substance & $\begin{array}{l}\text { Experiment } \\
\text { Method }\end{array}$ & $\begin{array}{l}\text { Background } \\
\text { Gas:pressure }\end{array}$ & Results & Ref. \\
\hline \multirow[t]{5}{*}{$n$-Propanol } & TDCC & He: 1050 Torr & $2<S_{\mathrm{cr}}<6,260<T<310 \mathrm{~K}$ & 99 \\
\hline & & - & $0.5<\log \left(S_{\mathrm{cr}}\right)<1.5,0.4<T_{\mathrm{r}}<0.55$ & 106 \\
\hline & & He: $1340-1460$ Torr & $2.4<S_{\mathrm{cr}}<2.2,270<T<300 \mathrm{~K}$ & 23 \\
\hline & ST & Dry air & $0.5<P<10$ Torr, $220<T<270 \mathrm{~K}$ at $\mathrm{ONC}$ & 115 \\
\hline & & Ar: $1 \mathrm{~atm}$ & $\begin{array}{l}0.05<P<10 \text { Torr, } 210<T<260 \mathrm{~K} \\
1 \mathrm{e}+7<J<1 \mathrm{e}+9 \text { at } \mathrm{ONC}\end{array}$ & 17 \\
\hline $\begin{array}{l}\text { Propanonic } \\
\text { acid }\end{array}$ & TDCC & He:77-737 Torr & $4<S_{\mathrm{cr}}<28,240<T<310 \mathrm{~K}$ & 9 \\
\hline Silane & ST & Ar: 50 Torr & $0<\ln \left(S_{\mathrm{cr}}\right)<12,1500<T<2800 \mathrm{~K}$ at $\mathrm{ONC}$ & 62 \\
\hline Silicon & ST & Ar & $\begin{array}{l}0.5<\log (C P)<2 \text { at ONC (avalanche), } \\
1900<T<2400 \mathrm{~K}\end{array}$ & 70 \\
\hline \multirow{2}{*}{$\begin{array}{l}\text { Silicon } \\
\text { oxide }\end{array}$} & ST & $\mathrm{Ar}, \mathrm{N}_{2} \mathrm{O} / \mathrm{Ar}$ & $0<\log (C P)<2$ at $\mathrm{ONC}$ (avalanche), $1200<T<3850 \mathrm{~K}$ & 70 \\
\hline & FA & $\mathrm{H}_{2}: 20-50$ Torr & $\begin{array}{l}1 \mathrm{c}+3<S<1 \mathrm{c}+6,730<T<980 \mathrm{~K} \\
J \sim 1 \mathrm{e}+11 \text { at } \mathrm{ONC}\end{array}$ & 8 \\
\hline $\begin{array}{l}\text { Silicon } \\
\text { tetrachloride }\end{array}$ & TDCC & He:658-1092 Torr & $2<S_{\mathrm{Cr}}<8,235<T<300 \mathrm{~K}$ & 27 \\
\hline Silver & FA & $\mathrm{H}_{2}: 250-500$ Torr & $\begin{array}{l}5<\ln (S)<40,500<T<950 \mathrm{~K} \\
1 \mathrm{e}+9<J<1 \mathrm{e}+11 \text { at ONC }\end{array}$ & 79 \\
\hline \multirow{2}{*}{$\begin{array}{l}\text { Stearic } \\
\text { acid }\end{array}$} & TDCC & He:9.6-47.9 Torr & $30<S_{\mathrm{cr}}<200,340<T<390 \mathrm{~K}$ & 35 \\
\hline & & $\mathrm{He}: 4-41 \mathrm{kPa}$ & $\begin{array}{l}10<S_{\mathrm{cr}}<400,330<T<410 \mathrm{~K} ; \text { upward and } \\
\text { downward TDCC modes }\end{array}$ & 30 \\
\hline Styrene & TDCC & He:206-999 Torr & $2<S_{\mathrm{cr}}<14,240<T<300 \mathrm{~K}$ & 18 \\
\hline \multirow[t]{3}{*}{$\begin{array}{l}\text { Sulfur } \\
\text { hexafluoride }\end{array}$} & LN & $\mathrm{He}, \mathrm{Ar}$ & $1 \mathrm{e}-3<P P(\mathrm{sh})<1$ Torr, $20<T<100 \mathrm{~K}$ at $\mathrm{ONC}$ & 26 \\
\hline & SN & Ar:292-794 Torr & $0.08<P P(\mathrm{sh})<4 \mathrm{Torr}, 75<T<120 \mathrm{~K}$ at $\mathrm{ONC}$ & 44 \\
\hline & & Ar:24-167 bar & $\begin{array}{l}5 \mathrm{e}-2<P P(\mathrm{sh})<5 \mathrm{Torr}, 20<T<100 \mathrm{~K} \text { at } \mathrm{ONC}: \\
0.9<P P(\mathrm{a})<2 \text { Torr, } 20<T<60 \mathrm{~K} \text { at } \text { ONC; } T_{i}-293 \mathrm{~K}\end{array}$ & 131 \\
\hline \multirow{3}{*}{$\begin{array}{l}1,1,2,2- \\
\text { tetra- } \\
\text { chloroethanc }\end{array}$} & TDCC & - & $0.8<\log \left(S_{\mathrm{cr}}\right)<2,0.35<T_{\mathrm{r}}<0.55$ & 106 \\
\hline & & $\mathrm{H}_{2}$, He:80-95 Torr & $0.6<\log \left(S_{\mathrm{cr}}\right)<2.0,230<T<350 \mathrm{~K}$ & 133 \\
\hline & & $\begin{array}{l}\text { He:67-1808 Torr } \\
\mathrm{H}_{2}: 104-1680 \text { Torr }\end{array}$ & $4<S_{\mathrm{cr}}<80,230<T<340 \mathrm{~K}$ & 6 \\
\hline $\begin{array}{l}\text { Tin } \\
\text { tetrachloride }\end{array}$ & TDCC & He:588-838 Torr & $2<S_{\mathrm{cr}}<14,240<T<310 \mathrm{~K}$ & 47 \\
\hline $\begin{array}{l}\text { Titanium } \\
\text { tetrachloride }\end{array}$ & TDCC & He:588-838 Torr & $5<S_{\mathrm{cr}}<30,240<T<310 \mathrm{~K}$ & 47 \\
\hline
\end{tabular}


TABLE 1. Unary system critical supersaturation ratio - Continued

\begin{tabular}{|c|c|c|c|c|}
\hline Substance & $\begin{array}{l}\text { Experiment } \\
\text { Method }\end{array}$ & $\begin{array}{l}\text { Background } \\
\text { Gas:pressure }\end{array}$ & Results & Ref. \\
\hline \multirow[t]{4}{*}{ Toluene } & TDCC & $\mathrm{H}_{2}, \mathrm{He}: 80-95$ Torr & $0.4<\log \left(S_{\mathrm{cr}}\right)<1.6,210<T<330 \mathrm{~K}$ & 133 \\
\hline & & $\mathrm{H}_{2}: 182-2044$ Torr & $1<S_{\mathrm{cr}}<40,220<T<320 \mathrm{~K}$ & 7 \\
\hline & & He:178-2085 Torr & $1<S_{\mathrm{cr}}<40,220<T<320 \mathrm{~K}$ & 7 \\
\hline & ECC & Ar. 1200 Torr & $8<S_{\mathrm{cr}}<40,215<T<267 \mathrm{~K}$ & 12 \\
\hline \multirow[t]{2}{*}{$\begin{array}{l}\text { Vinyl } \\
\text { acetate }\end{array}$} & TDCC & $\mathrm{He}$ & $\begin{array}{l}1<S_{\mathrm{cr}}<6,260<T<300 \mathrm{~K} \text {; benzoyl peroxide } \\
\text { used as initiator }\end{array}$ & 68 \\
\hline & & He:868-1152 Torr & $2<S_{\mathrm{cr}}<8,240<T<300 \mathrm{~K}$ & 37 \\
\hline \multirow[t]{9}{*}{ Water } & ST & $\mathrm{Ar}$ & $\begin{array}{l}0.05<P<100 \text { Torr, } 200<T<260 \mathrm{~K} \\
\text { le }+7<J<1 \mathrm{l}+9 \text { at } \mathrm{ONC}\end{array}$ & 73 \\
\hline & & $\begin{array}{l}\text { Ar,He,Air: } \\
2-62 \text { Torr }\end{array}$ & $1<P<100$ Torr, $210<T<280 \mathrm{~K}$ at $\mathrm{ONC}$ & 155 \\
\hline & & Ar:773-1732 Torr & $0.1<P P(w)<3$ Torr, $180<T<230 \mathrm{~K}$ at $\mathrm{ONC}$ & 33 \\
\hline & & $\mathrm{Ar}$ & $1<P P(w)<20$ Torr, $230<T<255 \mathrm{~K}$ at $\mathrm{ONC}$ & 65 \\
\hline & ECC & Ar:860-950 Torr & $3<S_{\mathrm{cr}}<10,230<T<290 \mathrm{~K}$ & 60 \\
\hline & LN & - & $10<P<500 \mathrm{Torr}, 230<T<300 \mathrm{~K}$ at $\mathrm{ONC}$ & 42 \\
\hline & FJ & $0.2-3$ bar & $100<P<200 \mathrm{Torr}, 280<T<320 \mathrm{~K}$ at ONC & 32 \\
\hline & TDCC & $\begin{array}{l}\text { He:728-1103 Torr } \\
\mathrm{H}_{2}: 773-1071 \text { Torr }\end{array}$ & $2<S_{\mathrm{cr}}<4,280<T<330 \mathrm{~K}$ & 34 \\
\hline & SN & Air, 1 atm & $0.01<P P(w)<0.1$ atm, $210<T<260 \mathrm{~K}$ & 113 \\
\hline Xenon & ST & $\mathrm{He}, \mathrm{Ar}$ & $100<P P(x)<2500 \mathrm{~Pa}, 70<T<110 \mathrm{~K}$ at $\mathrm{ONC}$ & 100 \\
\hline$m$-Xylene & TDCC & He:780-1108 Torr & $\begin{array}{l}1<S<15,260<T<320 \mathrm{~K} \\
J \sim 2-3 \text { at ONC }\end{array}$ & 36 \\
\hline \multirow[t]{3}{*}{$o$-Xylene } & TDCC & He:80-95 Torr & $0.5<\log \left(S_{\mathrm{cr}}\right)<1.3,260<T<350 \mathrm{~K}$ & 133 \\
\hline & & He:803-1781 Torr & $3<S_{c r}<20,260<T<340 \mathrm{~K}$ & 7 \\
\hline & & $\mathrm{H}_{2}: 149-1804$ Torr & $3<S_{\mathrm{cr}}<20,260<T<340 \mathrm{~K}$ & 7 \\
\hline Zinc & SN & He & $\begin{array}{l}2<P P(z)<30 \text { psia, } 500<T<1000 \mathrm{~K} \text { at } \mathrm{ONC} \\
3 \mathrm{e}+19<J<3 \mathrm{e}+24 \text { at } \mathrm{ONC}\end{array}$ & 119 \\
\hline
\end{tabular}

Legend:

$C P$ : critical pressure (units specified)

$J:$ nucleation rate (particles $/ \mathrm{cm}^{3}$ s)

In, log : logarithm - base e, base 10

ONC : onset of nucleation/condensation

$P:$ pressure (units specified)

$P P .:$ partial pressure (substance and units specified)

$S$ : supersaturation

$S_{\mathrm{cr}}$ : critical supersanuration

$T:$ temperature (units specified)

$T_{i}:$ initial temperature (units specified)

$T_{r}:$ reduced temperature

- : not specified 
TABLE 2. Unary system nucleation rate measurement

\begin{tabular}{|c|c|c|c|c|}
\hline Substance & $\begin{array}{l}\text { Experiment } \\
\text { Method }\end{array}$ & $\begin{array}{l}\text { Background } \\
\text { Gas:pressure }\end{array}$ & Results & Ref. \\
\hline$n$-Butanol & TPEC & Ar: $77.33 \mathrm{kPa}$ & $6.1 \mathrm{e}+5<J<2 \mathrm{e}+9,4.39<\mathrm{S}<14.45,-15<T \mathrm{i}<45^{\circ} \mathrm{C}$ & 15 \\
\hline \multirow[t]{7}{*}{$\begin{array}{l}\text { Dibutyl } \\
\text { phthalate }\end{array}$} & GFDC & Ar:STP & $\begin{array}{l}1<\log (J)<6,2.3<\log (S)<2.7,16<T<2 \\
0.5<\log (J)<4,77<T<118{ }^{\circ} \mathrm{C} ; 0.01<\mathrm{PP}<0.42 \mathrm{Torr}\end{array}$ & 57 \\
\hline & & $\mathrm{CO}_{2}: 0.1 \mathrm{n} 0.2 \mathrm{MPa}$ & $0.5<\log (J)<5.5,1.0<\log (S)<3.0,2<T<63^{\circ} \mathrm{C}$ & 51 \\
\hline & & He:0.1n0.25 MPa & $\begin{array}{l}1<\log (J)<6.5,1.5<\log (S)<3.5 ; \\
1<\log (J)<6,1.8<\log (S)<2.8 ; 1<\operatorname{Tn}<61{ }^{\circ} \mathrm{C}\end{array}$ & 52 \\
\hline & PSM & $\mathrm{N}_{2}$ & $\begin{array}{l}P N C, 160<S<240,30<T<50{ }^{\circ} \mathrm{C}, \mathrm{ZnCl} 2 \text { seed, } \\
105<T_{i}<125^{\circ} \mathrm{C} \text {; varying } \mathrm{N}_{2} \text { flow rate }\end{array}$ & 40 \\
\hline & & $\mathrm{N}_{2}$ & $\begin{array}{l}P N C, 100<S<300,105<T_{\mathrm{n}}<125^{\circ} \mathrm{C} \\
\text { nucleation time measured }\end{array}$ & 129 \\
\hline & LFAG & $\mathrm{N}_{2}$ & $P N C, 50<T_{\mathrm{s}}<105^{\circ} \mathrm{C}$ & 69 \\
\hline & KUST & inert gas & $\begin{array}{l}1<\log (J)<6,2<\log (S)<3,19.8<T_{\mathrm{c}}<21.5^{\circ} \mathrm{C} \\
\text { and } 43.8<T_{\mathrm{c}}<45.5^{\circ} \mathrm{C}\end{array}$ & 144 \\
\hline \multirow[t]{2}{*}{$\begin{array}{l}\text { Dibutyl } \\
\text { sebacate }\end{array}$} & KUST & Ar,air & $\begin{array}{l}-3<\log (J)<7,2<\log (S)<3,19.8<T_{\mathrm{c}}<21.5^{\circ} \mathrm{C} \\
\text { and } 43.8<T_{\mathrm{c}}<45.5^{\circ} \mathrm{C}\end{array}$ & 144 \\
\hline & & Ar,air & $2<\log (J)<6,2.25<\log (S)<2.5,45.1<T<45.5^{\circ} \mathrm{C}$ & 145 \\
\hline $\begin{array}{l}\text { Dihexyl } \\
\text { phthalate }\end{array}$ & KUST & Ar,air & $\begin{array}{l}1<\log (J)<7,2<\log (S)<3.5,19.8<T_{c}<21.5^{\circ} \mathrm{C} \\
\text { and } 43.8<T_{c}<45.5^{\circ} \mathrm{C}\end{array}$ & 144 \\
\hline $\begin{array}{l}\text { Dihexyl } \\
\text { sebacate }\end{array}$ & KUST & Ar,air & $\begin{array}{l}0.5<\log (J)<8,2<\log (S)<3,19.8<T_{c}<21.5^{\circ} \mathrm{C} \\
\text { and } 43.8<T_{c}<45.5^{\circ} \mathrm{C}\end{array}$ & 144 \\
\hline $\begin{array}{l}\text { Dioctyl } \\
\text { phthalate }\end{array}$ & KUST & Ar,air & $\begin{array}{l}1<\log (J)<8,2.5<\log (S)<3.6,19.8<T_{\mathrm{c}}<21.5^{\circ} \mathrm{C} \\
\text { and } 43.8<T_{\mathrm{c}}<45.5^{\circ} \mathrm{C}\end{array}$ & 144 \\
\hline $\begin{array}{l}\text { Dipentyl } \\
\text { sebacate }\end{array}$ & KUST & Ar,air & $\begin{array}{l}1<\log (J)<8,2<\log (S)<3.5,19.8<T_{c}<21.5^{\circ} \mathrm{C} \\
\text { and } 43.8<T_{c}<45.5^{\circ} \mathrm{C}\end{array}$ & 144 \\
\hline \multirow[t]{2}{*}{$\begin{array}{l}\text { Di-2-ethylhexyl } \\
\text { sebacate }\end{array}$} & KUST & Ar,air & $\begin{array}{l}0<\log (J)<8,2.5<\log (S)<4,19.8<T_{c}<21.5^{\circ} \mathrm{C} \\
\text { and } 43.8<T c<45.5^{\circ} \mathrm{C}\end{array}$ & 144 \\
\hline & TJ & $\mathrm{N}_{2}$ & $1 \mathrm{e}+5<N<1 \mathrm{e}+11,135<T_{\mathrm{c}}<160^{\circ} \mathrm{C}$; cold sheath & 117 \\
\hline \multirow[t]{6}{*}{ Ethanol } & TDCC & He:1010n114 Torr & $1<J<2000,2<S<3,297 \mathrm{~K}$ & 141 \\
\hline & & $\mathrm{He}: 0.5 \mathrm{n} 1.5 \mathrm{MPa}$ & $\begin{array}{l}5<\log (J)<7,1.7<S<2,310<T<370 \mathrm{~K} \\
2.7 \mathrm{e}+4<\mathrm{PP}<3.6 \mathrm{e}+5 \mathrm{~Pa}\end{array}$ & 93 \\
\hline & & He: $1050 \mathrm{n} 1100$ Torr & $1<J<1 e+3,2.1<S<3.1,262<T<292 \mathrm{~K}$ & 99 \\
\hline & TPEC & $\mathrm{Ar}$ & $1 \mathrm{e}+5<J<1 \mathrm{e}+10,2<S<5,-15<T_{i}<45^{\circ} \mathrm{C}$ & 92 \\
\hline & & Ar:77.33 kPa & $1 \mathrm{e}+5<J<1 \mathrm{e}+10,2<S<5,-15<T_{i}<45^{\circ} \mathrm{C}$ & 15 \\
\hline & $\mathrm{ECC}$ & Ar: 1200 Torr & $1<J<1000,2.4<S<2.9,252<T<272 \mathrm{~K}$ & 13 \\
\hline \multirow[t]{2}{*}{ Glycerine } & GFDC & $\mathrm{N}_{2}: 0.9 \mathrm{~atm}$ & $0<\log (J)<5,1.8<\log (S)<3.1,266<T<290 \mathrm{~K}$ & 53 \\
\hline & & Ar:STP & $0<\log (J)<4,289<T<306 \mathrm{~K}$, varying $S$ & 57 \\
\hline$n$-Hexanol & TPEC & Ar:75.99 $\mathrm{kPa}$ & $1 \mathrm{e}+5<J<1 \mathrm{e}+10,8<S<20,15<T_{i}<55^{\circ} \mathrm{C}$ & 15 \\
\hline $\begin{array}{l}\text { Iron Penta- } \\
\text { carbonyl }\end{array}$ & ST & Ar & $2<P N C<5 \mathrm{e}+14,1000<T<1700 \mathrm{~K}, 2<\ln (S)<20$ & 89 \\
\hline
\end{tabular}


REVIEW OF VAPOR TO LIQUID HOMOGENEOUS NUCLEATION EXPERIMENTS

TABLE 2. Unary system nucleation rate measurement - Continued

\begin{tabular}{|c|c|c|c|c|}
\hline Substance & $\begin{array}{l}\text { Experiment } \\
\text { Method }\end{array}$ & $\begin{array}{l}\text { Background } \\
\text { Gas:pressure }\end{array}$ & Results & Ref. \\
\hline \multirow[t]{2}{*}{ Mercury } & TDCC & $\mathrm{He}$ & $0<\ln (F)<5,258<T<398 \mathrm{~K}, 1<S<80000$ & 10 \\
\hline & & light, inert & $0<F<500,250<T<320 \mathrm{~K}, 1 \mathrm{e}+3<S<1 \mathrm{e}+5$ & 66 \\
\hline \multirow[t]{2}{*}{ Methanol } & TPEC & Ar & $1 \mathrm{e}+5<J<1 \mathrm{e}+10,2<S<5,-15<T,<25^{\circ} \mathrm{C}$ & 92 \\
\hline & & Ar: $77.33 \mathrm{kPa}$ & $1 \mathrm{e}+5<J<1 \mathrm{e}+10,2<S<5,-25<T \mathrm{i}<25^{\circ} \mathrm{C}$ & 15 \\
\hline $\begin{array}{l}\text { Nickel } \\
\text { carbonyl }\end{array}$ & ST & $\mathrm{He}, \mathrm{Ar}$ & $13<\log (P N C)<19,1000<T<3500 \mathrm{~K}$ & 84 \\
\hline \multirow[t]{5}{*}{$n$-Nonane } & TDCC & He:895-1155 & $\begin{array}{l}0.1<J<10,0<t_{d}<680 \mathrm{~min} ., 350<T<400 \\
350-880 \mathrm{ppm} \text { benzocyclobutenol in } \\
\text { liquid pool; thermally induced nucleation }\end{array}$ & 95 \\
\hline & & $\mathrm{He}$ & $\begin{array}{l}0<N<100,0<t_{d}<200 \mathrm{~min} ., 356<T<396 \mathrm{~K} \\
\text { benzocyclobutenol doped in liquid pool; } \\
\text { thermally induced nucleation }\end{array}$ & 96 \\
\hline & & He: $1.97-187$ & $1 \mathrm{e}-5<J<1 \mathrm{e}+2, \cdot 1<S<50,233<T<315 \mathrm{~K}$ & 11 \\
\hline & ECC & $\mathrm{Ar}$ & $2<P N C<800,10<S<100,215<T<270 \mathrm{~K}$ & 14 \\
\hline & TPEC & Ar:76-114k & $5 \mathrm{e}+5<J<5 \mathrm{e}+9,50<S<2000,195<T<235 \mathrm{~K}$ & 16 \\
\hline l-Pentanol & TPEC & $\mathrm{He}, \mathrm{Ar}, \mathrm{N}_{2}$ & $1 \mathrm{e}+5<J<1 \mathrm{e}+10,6<S<12,250<T<275 \mathrm{~K}$ & 120 \\
\hline$n$-Pentanol & TPEC & Ar: $78.26 \mathrm{kPa}$ & $1 \mathrm{e}+6<J<2 \mathrm{e}+9,7<S<15,250<T<275 \mathrm{~K}$ & 15 \\
\hline$i$-Propanol & TDCC & He: $1050-130$ & $0.1<J<200,2.3<S<3.5,261<T<294 \mathrm{~K}$ & 99 \\
\hline \multirow[t]{3}{*}{ n-Propanol } & TPEC & $\mathrm{N}_{2}$ & $2 \mathrm{e}+5<J<2 \mathrm{e}+9,2<S<5,3<T_{i}<25^{\circ} \mathrm{C}$ & 48 \\
\hline & TDCC & He:900-1300 & $0.4<J<300,2<S<4.5,261<T<298 \mathrm{~K}$ & 99 \\
\hline & TPEC & Ar:77.33 kPa & $3.5 \mathrm{e}+5<J<2.2 \mathrm{e}+9,3<S<8,235<T<296 \mathrm{~K}$ & 15 \\
\hline Styrenc & ECC & Ar & $\begin{array}{l}0.3<P N C<500,4<S<26,15<T<25^{\circ} \mathrm{C} \\
02 \text { used as inhibitor }\end{array}$ & 81 \\
\hline $\begin{array}{l}\text { Sulfur } \\
\text { Hexafluoride }\end{array}$ & $\mathbf{L N}$ & $\mathrm{He}, \mathrm{Ar}$ & $\begin{array}{l}0<P N C<8 \mathrm{e}+19,1<\mathrm{P}<7 \text { bar, } 20<T<160 \mathrm{~K} \\
3-12.5 \% \text { SF6 in Ar }\end{array}$ & 26 \\
\hline \multirow[t]{2}{*}{ Toluene } & ECC & Ar:200-1200 & $\begin{array}{l}1<P N C<700 ;-5<T_{i}<45^{\circ} \mathrm{C} \text {; } \\
0.01 \text { sec. nucleation pulse }\end{array}$ & 135 \\
\hline & ECC & Ar & $1<P N C<800,1<S<60$ at $215<T<267 \mathrm{~K}$ & 12 \\
\hline
\end{tabular}


TABle 2. Unary system nucleation rate measurement - Continued

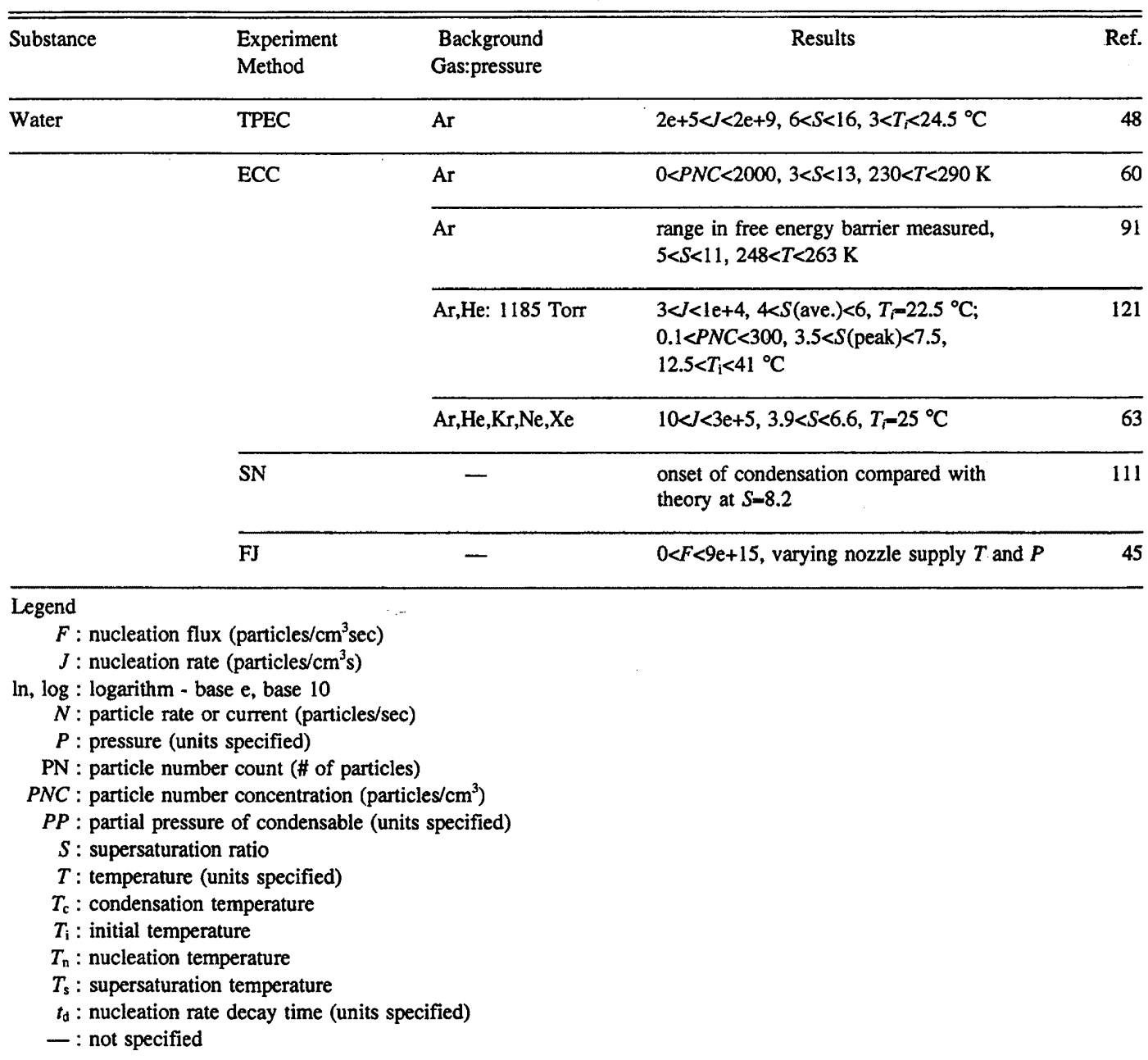


REVIEW OF VAPOR TO LIQUID HOMOGENEOUS NUCLEATION EXPERIMENTS

TABLE 3. Binary system nucleation measurements

\begin{tabular}{|c|c|c|c|c|}
\hline Substance & $\begin{array}{l}\text { Experiment } \\
\text { Method }\end{array}$ & $\begin{array}{l}\text { Background } \\
\text { Gas:pressure }\end{array}$ & Results & Ref. \\
\hline $\begin{array}{l}\text { Acetic acid/ } \\
\text { Water }\end{array}$ & ST & $\mathrm{N}_{2}$ & $\begin{array}{l}0<A C(\mathrm{aa})<7,0<A C(\mathrm{w})<6,270<T<290 \mathrm{~K} \\
J \sim 1 \mathrm{e}+16 \text { at } \mathrm{ONC}\end{array}$ & 24 \\
\hline \multirow[t]{2}{*}{$\begin{array}{l}\text { Acetone/ } \\
\text { Water }\end{array}$} & TDCC & $\mathrm{He}$ & $\begin{array}{l}0<A C(\mathrm{a})<3,0<A C(\mathrm{w})<5, T=273 \mathrm{~K} \\
J \sim 2-3 \text { at } \mathrm{ONC}\end{array}$ & 104 \\
\hline & & He:1198-128 & $\begin{array}{l}0.8<A C(\mathrm{a})<5,0<A C(\mathrm{w})<3, T=273 \mathrm{~K} \\
J \sim 1 \text { at } \mathrm{ONC}\end{array}$ & 39 \\
\hline $\begin{array}{l}n \text {-Butanol } \\
\text { Water }\end{array}$ & $\mathrm{ECC}$ & $\mathrm{Ar}$ & $\begin{array}{l}A C \text { varied for butanol and water, } T=263 \mathrm{~K} \text {; } \\
1 \mathrm{e}+5<J<1 \mathrm{e}+9\end{array}$ & 75 \\
\hline $\begin{array}{l}\text { Dibutyl phthalate } \\
\text { Dioctyl phthalatc }\end{array}$ & PSM & Air & $\begin{array}{l}20<S(\mathrm{dbp})<200,60<\mathrm{S}(\mathrm{dop})<1000,100<T<155^{\circ} \mathrm{C} \\
1 \mathrm{e}+2<P N C<1 \mathrm{e}+7\end{array}$ & 20 \\
\hline $\begin{array}{l}\text { Dtibutyl phthalate } \\
\text { Glycerin }\end{array}$ & $\mathrm{FC}$ & $\mathrm{Ar}$ & $\begin{array}{l}1.6<\log (\mathrm{S})(\mathrm{g})<2,1.7<\log (\mathrm{S})(\mathrm{DBP})<2,35<T_{\mathrm{c}}<41^{\circ} \mathrm{C} ; \\
1<\log (J)<5\end{array}$ & 109 \\
\hline $\begin{array}{l}\text { Diethylhe phthalate } \\
\text { Dioctyl phthalate }\end{array}$ & LCJ & $\mathrm{N}_{2}: 1 \mathrm{~atm}$ & $\begin{array}{l}3 \mathrm{e}+7<P N C<6 \mathrm{e}+7 \text {, varying mass } \% \text { DHP in DOP, } \\
T_{\mathrm{r}}=270^{\circ} \mathrm{C}\end{array}$ & 67 \\
\hline $\begin{array}{l}\text { Dicthylhe phthalate } \\
\text { Squalane }\end{array}$ & LCJ & $\mathrm{N}_{\mathrm{L}}: 1 \mathrm{~atm}$ & $\begin{array}{l}3 \mathrm{e}+7<P N C<1 \mathrm{e}+8, \text { varying mass } \% \mathrm{DHP} \text { in } \mathrm{SQ} \text {, } \\
T_{i=270^{\circ} \mathrm{C}}\end{array}$ & 67 \\
\hline $\begin{array}{l}\text { Ethanol/ } \\
\text { Methanol }\end{array}$ & TDCC & He:1208-123 Torr & $\begin{array}{l}0<A C(\mathrm{e})<2.5,0<A C(\mathrm{~m})<2, T=280 \mathrm{~K} \text {; } \\
J \sim 1 \text { at } \mathrm{ONC}\end{array}$ & $\begin{array}{r}72 \\
108\end{array}$ \\
\hline \multirow[t]{2}{*}{$\begin{array}{l}\text { Ethanol/ } \\
n \text {-Propanol }\end{array}$} & ST & $\begin{array}{l}\text { Dry air: } \\
770-1500 \text { Torr }\end{array}$ & $\begin{array}{l}0<A C(\mathrm{e})<2.5,3.55<A C(\mathrm{p})<7.5,228<T \\
\text { at ONC }\end{array}$ & 107 \\
\hline & TDCC & He:974-1224 Torr & $\begin{array}{l}0<A C(\mathrm{e})<2.4,0<A C(\mathrm{p})<3.5, T=280 \mathrm{~K} \\
J \sim 1 \text { at } \mathrm{ONC}\end{array}$ & 108 \\
\hline \multirow[t]{7}{*}{$\begin{array}{l}\text { Ethanol/ } \\
\text { Water }\end{array}$} & TDCC & $\mathrm{He}$ & $\begin{array}{l}0<A C(\mathrm{e})<2,0<A C(\mathrm{w})<3.5, T=293 \mathrm{~K} \\
J \sim 2-3 \text { at } \mathrm{ONC}\end{array}$ & 104 \\
\hline & & He:1201-157 Torr & $\begin{array}{l}0<A C(\mathrm{e})<2.0,0<A C(\mathrm{w})<3.5, T=293.2 \mathrm{~K} \\
J \sim 1 \text { at } \mathrm{ONC}\end{array}$ & 36 \\
\hline & ST & $\mathrm{N}_{2}: 2$ bar & $\begin{array}{l}0<A C(\mathrm{e})<3,0<A C(\mathrm{w})<7,270<T<291 \mathrm{~K} \\
1 \mathrm{c}+10<J<1 \mathrm{c}+15 \text { at } \mathrm{ONC}\end{array}$ & 138 \\
\hline & & $\begin{array}{l}\text { Dry air: } \\
771-1410 \text { Torr }\end{array}$ & $\begin{array}{l}1.4<A C(\mathrm{e})<5.85,0.78<A C(\mathrm{w})<11.12,220 \\
<T_{\mathrm{c}}<280 \mathrm{~K} \text {; at } \mathrm{ONC}\end{array}$ & 107 \\
\hline & LT & $\mathrm{N} 2: 2$ bar & $\begin{array}{l}0<A C(\mathrm{e})<4,0<A C(\mathrm{w})<7.2,257<T<272 \mathrm{~K} \\
1 \mathrm{e}+10<J<1 \mathrm{e}+15 \text { at } \mathrm{ONC}\end{array}$ & 71 \\
\hline & SN & $\mathrm{Ar}, \mathrm{Air}, \mathrm{N}_{2}$ & $2<P P(\mathrm{e}, \mathrm{w})<10$ Torr, $240<\mathrm{T}<260 \mathrm{~K}$ at ONC & 134 \\
\hline & $\mathrm{ECC}$ & Ar & $\begin{array}{l}0<A C(\mathrm{e})<3,0.4<A C(\mathrm{w})<7.5,263<T<293 \mathrm{~K} \\
1 \mathrm{e}+3<J<1 \mathrm{e}+5 \text { for varying MF; } \\
1<P N C<1000,0.6<A C(\mathrm{e})<0.7, T_{i}=25 \mathrm{C}\end{array}$ & 19 \\
\hline Ethylbenzene/ & TDCC & He:517-780 Torr & $1<\mathrm{S}_{\mathrm{cr}}<14,250<T<350 \mathrm{~K}, 5 \%$ styrene mix & 18 \\
\hline \multirow[t]{2}{*}{ Styrene } & & He:878-1000 Torr & $1<\mathrm{S}_{\mathrm{ct}}<10,270<T<330 \mathrm{~K}, 25 \%$ styrene $\mathrm{mix}$ & 18 \\
\hline & & $\mathrm{He}$ & $2<\mathrm{S}_{\mathrm{cr}}<10,280<T<320 \mathrm{~K}, 0.17$ and $0.25 \mathrm{MF}$ styrene & 68 \\
\hline $\begin{array}{l}\text { Iron/ } \\
\text { silicon }\end{array}$ & ST & $\mathrm{Ar}$ & $\begin{array}{l}0<\log (C P)<1 \text { Torr at ONC (avalanche), } \\
1500<T<2500 \mathrm{~K}\end{array}$ & 70 \\
\hline
\end{tabular}


TABLE 3. Binary system nucleation measurements - Continued

\begin{tabular}{|c|c|c|c|c|}
\hline Substance & $\begin{array}{l}\text { Experiment } \\
\text { Method }\end{array}$ & $\begin{array}{l}\text { Background } \\
\text { Gas:pressure }\end{array}$ & Results & Ref. \\
\hline $\begin{array}{l}\text { Magnesium } \\
\text { Silicon oxide }\end{array}$ & FA & $\mathrm{H}_{2}$ & $-3.5<\log (P P(\mathrm{so})<-1.5$ Torr at $\mathrm{ONC}, 750<T<2500 \mathrm{~K}$ & 78 \\
\hline $\begin{array}{l}\text { Methane- } \\
\text { sulfonic acid/ }\end{array}$ & CFM & $\mathrm{N}_{2}$. & $\begin{array}{l}0.1<P N C<2 \mathrm{e}+5,0.15<R A<0.45,0.1<R H<0.65 \\
T=25^{\circ} \mathrm{C}\end{array}$ & 21 \\
\hline Water & MCFM & Dry air & $\begin{array}{l}2 \mathrm{e}-2<P N C<7 \mathrm{e}+5,0.074<R A<0.34,0.08<R H<0.7 \\
19<T<30^{\circ} \mathrm{C}\end{array}$ & 22 \\
\hline \multirow[t]{2}{*}{ Methanol/Water } & TDCC & He: $1300-1590$ Torr & $\begin{array}{l}0<A C(\mathrm{~m})<1.8,0<A C(\mathrm{w})<3.8, T=298 \mathrm{~K} \\
J \sim 2-3 \text { at } \mathrm{ONC}\end{array}$ & 23 \\
\hline & & $\mathrm{He}$ & $\begin{array}{l}0<A C(\mathrm{~m})<2.0,0<A C(\mathrm{w})<4, T=298 \mathrm{~K} \\
J \sim 1 \text { at } \mathrm{ONC}\end{array}$ & 104 \\
\hline $\begin{array}{l}\text { Methanol/ } \\
n \text {-Propanol }\end{array}$ & TDCC & He:1206-1220 Torr & $\begin{array}{l}0<A C(\mathrm{p})<3.5,0<A C(\mathrm{~m})<2, T=280 \mathrm{~K} \\
J \sim 1 \text { at } \mathrm{ONC}\end{array}$ & 108 \\
\hline $\begin{array}{l}\text { Nitric acid } \\
\text { Water }\end{array}$ & TDCC & $\cdots$ He:697-871 Torr & $\begin{array}{l}0<A C(\mathrm{na})<10,0<A C(\mathrm{w})<3.5,278<T<299 \mathrm{~K} \\
J \sim 2 \text { at } \mathrm{ONC}\end{array}$ & 56 \\
\hline $\begin{array}{l}\text { Nitrogen/ } \\
\text { Traces of impurities }\end{array}$ & EGJ & $\mathrm{N}_{2}: 150 \mathrm{bar}$ & $0<r N C<5 \mathrm{c}+2,0<$ pressure drop $<140$ bar & 83 \\
\hline \multirow[t]{3}{*}{$\begin{array}{l}n \text {-Propanol } \\
\text { Water }\end{array}$} & TDCC & $\mathrm{He}$ & $\begin{array}{l}0.1<A C(\mathrm{p})<5,0<A C(\mathrm{w})<3, T=298 \mathrm{~K} \\
J \sim 1 \text { at } \mathrm{ONC}\end{array}$ & 72 \\
\hline & & $\mathrm{He}$ & $\begin{array}{l}0<A C(\mathrm{p})<3,0<A C(\mathrm{w})<4, T=298 \mathrm{~K} \\
J \sim 2-3 \text { at } \mathrm{ONC}\end{array}$ & 104 \\
\hline & & He: $1320-1540$ Torr & $\begin{array}{l}0<A C(\mathrm{p})<2.8,0<A C(\mathrm{w})<3.8, T=298 \mathrm{~K} \\
J \sim 2-3 \text { at } \mathrm{ONC}\end{array}$ & 23 \\
\hline $\begin{array}{l}\text { Styrene/ } \\
\text { Phenylacetylene }\end{array}$ & TDCC & He:535-560 Torr & 7 mole $\%(p), 4<S_{\mathrm{cr}}<9,260<T<300 \mathrm{~K}$ & 18 \\
\hline \multirow[t]{6}{*}{$\begin{array}{l}\text { Sulfuric acid/ } \\
\text { Water }\end{array}$} & TGMC & Air & $\begin{array}{l}10<P N C<4 \mathrm{e}+4,4 \mathrm{e}-7<P P(\mathrm{sa})<2 \mathrm{e}-6 \text { Torr } \\
T=25^{\circ} \mathrm{C}, 0.37<R H<0.65\end{array}$ & 87 \\
\hline & & Air & $\begin{array}{l}5 \mathrm{e}+7<J<2 \mathrm{e}+9,1.27 \mathrm{e}-3<\mathrm{S}(\mathrm{sa})<1.91 \mathrm{e}-3 \\
\mathrm{~S}(\mathrm{w})=0.52, T=\mathrm{ambient} ; \mathrm{le}+7<J<1 \mathrm{e}+9 \\
1.84 \mathrm{e}-3<\mathrm{S}(\mathrm{sa})<2.32 \mathrm{e}-3, \mathrm{~S}(\mathrm{w})=0.38, T=\text { ambient }\end{array}$ & 86 \\
\hline & $\mathrm{TA}$ & $\begin{array}{l}\text { Air: } 1 \mathrm{~atm} \\
\mathrm{~T}\end{array}$ & $\begin{array}{l}80<P N C<2 \mathrm{e}+4,5 \mathrm{e}-7<P P(\mathrm{sa})<1 \mathrm{e}-4 \text { Torr } \\
=20 \mathrm{C}, 15 \%<R H<70 \%, J>>1 \text { at ONC }\end{array}$ & 139 \\
\hline & ECC & Air & $\begin{array}{l}2<\mathrm{S}_{\mathrm{cr}}(\mathrm{w})<5.8,-35<T<-28^{\circ} \mathrm{C} \\
54.5<(\text { sa weight } \%)<67.3\end{array}$ & 112 \\
\hline & CFM & Dry air & $\begin{array}{l}1 \mathrm{e}-2<P N C<5 \mathrm{e}+5,0.1<R A<0.46,0 \\
<R H<0.65,20<T<30^{\circ} \mathrm{C} ; \\
0.001<J<700,0.1<R A<0.47,0.001 \\
<R H<0.7,20<T<30^{\circ} \mathrm{C} ; \\
0.001<J<300,0.03<R A<0.25,0.14 \\
<R H<0.28,20<T<30^{\circ} \mathrm{C} ; \\
0.01<J<100,0.04<R A<0.5,0.01 \\
<R H<0.5,20<T<30^{\circ} \mathrm{C}\end{array}$ & 74 \\
\hline & TDCC & $\begin{array}{l}\text { He:854-1056 Torr } \\
\mathrm{H}_{2}: 866-1041 \text { Torr }\end{array}$ & $\begin{array}{l}1 \mathrm{e}-8<A C(\mathrm{sa})<1 \mathrm{e}-2,1<A C(\mathrm{w})<3.5, T=298.2 \mathrm{~K} \\
J \sim 2 \text { at } \mathrm{ONC}\end{array}$ & 56 \\
\hline $\begin{array}{l}\text { Sulfur dioxide/ } \\
\text { Water }\end{array}$ & ECC & & $\begin{array}{l}1.75<\mathrm{S}_{\mathrm{cr}}<3.5,0<P P(\mathrm{sd})<3.0 \text { Torr, } T_{\mathrm{i}}=297 \mathrm{~K} \\
273.3<T_{\mathrm{r}}<289.8 \mathrm{~K}\end{array}$ & 126 \\
\hline
\end{tabular}


TABLE 3. Binary system nucleation measurements - Continued

\begin{tabular}{|c|c|c|c|c|}
\hline Substance & $\begin{array}{l}\text { Experiment } \\
\text { Method }\end{array}$ & $\begin{array}{l}\text { Background } \\
\text { Gas:pressure }\end{array}$ & Results & Ref. \\
\hline
\end{tabular}

Legend

$A C$ : activity (substance specified)

$C P$ : critical pressure, condensate(s) (units specified)

$J$ : nucleation rate (particles/cc-sec)

ln, log : logarithm - base e, base 10

ONC : onset of nucleation/condensation

$P N C$ : particle number concentraton (particles/cc)

$P P$ : partial pressure (condensable indicated)

$R A$ : relative acidity

$R H$ : relative humidity, water

$S$ : supersaturation (substance specified)

$S_{\mathrm{cr}}$ : critical supersaturation

$T:$ temperature (units specified)

$T_{c}$ : condensation temperature (units specified)

$T_{\mathrm{f}}$ : final temperature (units specified)

$T_{i}$ : initial temperature (units specified)

— : not specified 
TABLE 4. Photoinduced and ion-induced nucleation experiments

\begin{tabular}{|c|c|c|c|c|}
\hline Substance & $\begin{array}{l}\text { Experiment } \\
\text { Method }\end{array}$ & $\begin{array}{l}\text { Background } \\
\text { Gas:Pressure } \\
\text { (host Liquid) }\end{array}$ & Results & Ref. \\
\hline \multirow[t]{4}{*}{$\begin{array}{l}\text { Carbon } \\
\text { disulfide }\end{array}$} & \multirow[t]{4}{*}{ TDCC } & $\begin{array}{l}\text { He: } 107 \mathrm{kPa} \\
\text { (ethanol, } o \text {-xylene } \\
n \text {-butylbenzene } \\
\text { nonane) }\end{array}$ & $\begin{array}{l}225<E W<325, S \text { varied, } T, I \text { and nitric oxide } \\
\text { (to quench PIN) varied to maintain } R \sim 2 \text { drops } / \\
8 \mathrm{~cm}^{2} \mathrm{~s}, R-I \text { power law coefficient measured }\end{array}$ & 97 \\
\hline & & $\mathrm{He}$ & $\begin{array}{l}320<E W<337.1,2.7<S<7.25,250 \mathrm{~K}, 2<R<90 \text { counts } / \\
10 \mathrm{~s} \text { at various light intensities; } 3<R<40 \text { counts } / \\
2.1<\log (P P(\mathrm{~cd}))<2.5 \text { Torr, } I / I_{0}=0.546\end{array}$ & 98 \\
\hline & & $\begin{array}{l}\mathrm{H}_{2}: 1410 \text { Torr } \\
\text { (ethanol) }\end{array}$ & $\begin{array}{l}306<E W<328, S(\text { host })=1.75, T=252.9 \mathrm{~K}, 0.01<R<8 \\
\text { drops } / \mathrm{s}, I=3.8 \mathrm{e}-3 \mathrm{~W} / \mathrm{m}^{2} ; 1.08<S<2.08, R \sim 2 \\
\text { drops } / \mathrm{cm}^{2} \mathrm{~s}, 0.02<I<3 \mathrm{~W} / \mathrm{m} 2,30<\left[\mathrm{CS}_{2}\right] \mathrm{ppm}<3000\end{array}$ & 80 \\
\hline & & $\begin{array}{l}\text { He: } 107,214 \mathrm{kPa} \\
\text { (ethanol, nonane, } \\
o \text {-xylene) }\end{array}$ & $\begin{array}{l}266<T<355 \mathrm{~K} \text {, decay of PIN droplet count recorded } \\
\text { after blocking UV. }\end{array}$ & 122 \\
\hline Chlorine & TDCC & $\begin{array}{l}\text { He: } 1400 \text { Torr } \\
\text { (carbon } \\
\text { tetrachloride) }\end{array}$ & $\begin{array}{l}488<E W<514,1<S<4,276<T<281 \mathrm{~K}, 0<I_{\mathrm{c}}<2 \mathrm{e}+4 \mathrm{~mW}, \\
5<P P(\mathrm{cl})<10 \text { Torr } 450<E W<520,1.25<S(\text { host })<2.6 \\
3<I_{\mathrm{c}}<2000 \mathrm{~mW}: E W=488,20<I_{\mathrm{c}}<300 \mathrm{~mW}, 0<P P(\mathrm{cl}) \\
<9 \text { Torr }\end{array}$ & $\begin{array}{l}142 \\
143\end{array}$ \\
\hline $\begin{array}{l}\text {-iodide } \\
\text { (Methyl, Propyl, } \\
\text { Butyl, Octyl) }\end{array}$ & TDCC & $\begin{array}{l}\text { He } \\
\text { (nonane) }\end{array}$ & $210<E W<330,-1<\log (R)<3 \mathrm{drops} / \mathrm{cm}^{3} \mathrm{~s}$ & 90 \\
\hline $\begin{array}{l}\text { Nickel } \\
\text { Carbonyl }\end{array}$ & TDCC & $\begin{array}{l}\text { He:255-275 Torr } \\
\text { (methanol) }\end{array}$ & $\begin{array}{l}E W=300, S(\text { host })=1.78, T=251 \mathrm{~K}, \text { PIN measured } \\
\text { as function of total pressure and } I,\left[\mathrm{Ni}(\mathrm{CO})_{4}\right]=7.7 \mathrm{e}-4 \mathrm{M} \text {, } \\
P P(\mathrm{nc})=0.005 \text { Torr }\end{array}$ & 61 \\
\hline $\begin{array}{l}\text { Nitrogen } \\
\text { dioxide }\end{array}$ & TDCC & $\begin{array}{l}\text { He: } 800-810 \text { Torr } \\
\text { (nonane) }\end{array}$ & $\begin{array}{l}E W-370, S(\text { host })=3.97, T-305 \mathrm{C}, 10<R<55 \mathrm{drops} / \\
\mathrm{cm}^{3} \text { s. varying relative excitation intensity. } \\
1.1<P P\left(\mathrm{NO}_{2}\right)<1.45 \text { Torr }\end{array}$ & 90 \\
\hline $\begin{array}{l}\text { Nitrogen } \\
\text { oxide }\end{array}$ & TDCC & $\begin{array}{l}\text { He: } 107 \mathrm{kPa} \\
\text { (nonane) }\end{array}$ & $\begin{array}{l}225<\mathrm{EM}<400,278<T<351 \mathrm{~K}, I \text { varied to maintain } \\
R \sim 2 \text { drops } / 8 \mathrm{~cm}^{2} \mathrm{~s} \text {. PIN decay constant measured. } \\
R-I \text { power law coefficient measured }\end{array}$ & 97 \\
\hline $\begin{array}{l}\text { Octaorganyl } \\
\text { silsesquioxane }\end{array}$ & LFC & Ar & $\begin{array}{l}185<E W<220,4.7<\log (S)<5.5, T=292 \mathrm{~K}, \\
0<\log (P N C)<5 \text { drops } / \mathrm{s} \text {, ethyl- } T_{8}, \text { vinyl- } T_{8} \\
\text { and phenyl- } T_{8} \text { radicals formed }\end{array}$ & 110 \\
\hline \multirow[t]{3}{*}{$\begin{array}{l}\text { Sulfur } \\
\text { dioxide }\end{array}$} & \multirow[t]{3}{*}{ TDCC } & $\begin{array}{l}\mathrm{He} \\
\text { (methanol, ethanol } \\
\text { propanol, } n \text {-butane) }\end{array}$ & $\begin{array}{l}E W=U V \text { radiation, } S_{\max }(\text { host })=2.65,0<R<150 \mathrm{dr} \\
\text { drops } / \mathrm{cm}^{3} \mathrm{~s} \text {, initial }\left[\mathrm{SO}_{2}\right]=(3.15,4.15,4.24,4.48) \mathrm{e}+ \\
16 \mathrm{molecules} / \mathrm{cm}^{3}\end{array}$ & 123 \\
\hline & & $\begin{array}{l}\text { He:674 Torr } \\
\text { (water) }\end{array}$ & $\begin{array}{l}E W-380,1<R<20 \text { drops } / 100 \text { s. } 0.4<\left(I / I_{\mathrm{n}}\right)<1.0 \\
1.19 \mathrm{e}+17<\left[\mathrm{SO}_{2}\right]<2.19 \mathrm{e}+17 \text { molecules } / \mathrm{cm}^{3} \\
\text { triplet excitation }\end{array}$ & 126 \\
\hline & & $\begin{array}{l}\text { He } \\
\text { (water) }\end{array}$ & $\begin{array}{l}E W=305,2.7<A C(\mathrm{w})<3.21,0.55 \mathrm{e}-4<A C(\mathrm{sd})<9.26 \mathrm{e}-4 \\
T=298 \mathrm{~K}, 0.16<P P(\mathrm{sd})<2.83 \text { Torr for } R \sim 1 \mathrm{drops} / \mathrm{cm}^{3} \mathrm{~s} \\
30<R<2405 \text { drops } / 10 \mathrm{~cm}^{3} \mathrm{~s},\left(2.67<\left[\mathrm{SO}_{2}\right]<7.73\right) \mathrm{e}+ \\
16 \text { molecules } / \mathrm{cm}^{3},\left(1.6<\left[\mathrm{SO}_{2}\right]<5.77\right) 1 \mathrm{e}+9 \text { molecules } / \mathrm{cm}^{3}\end{array}$ & 146 \\
\hline \multirow[t]{2}{*}{$\begin{array}{l}\text { Sulfuric } \\
\text { acid }\end{array}$} & \multirow[t]{2}{*}{ FR } & Air, $\mathrm{N}_{2}$ & $\begin{array}{l}0.1<\text { dose }<2.0 \mathrm{mGy}, 8 \mathrm{e}+2<P N C<1 \mathrm{e}+5 \mathrm{drops} / \mathrm{cm}^{3}, R H \%= \\
17, T=20^{\circ} \mathrm{C},\left[\mathrm{SO}_{2}\right]=10 \mathrm{ppm}, 1 \mathrm{e}+5<[\text { ion }]<1 \mathrm{e}+6 \text { ions } / \mathrm{cm}^{3}\end{array}$ & 118 \\
\hline & & Synthetic air & $\begin{array}{l}E W=\mathrm{UV}, 1 \mathrm{e}+3<P N C<3 \mathrm{e}+5 \mathrm{drops} / \mathrm{cm}^{3}, 80<t_{\mathrm{r}}<1100 \mathrm{~s} \\
1<P N C \text { (under } \mathrm{UV}+\text { gamma) } / P N C \text { (under } \mathrm{UV})<200 \\
\text { (same } t_{\mathrm{r}} \text { ); water vapor catalyst }\end{array}$ & 103 \\
\hline
\end{tabular}


TABLE 4. Photoinduced and ion-induced nucleation experiments - Continued

\begin{tabular}{|c|c|c|c|c|}
\hline Substance & $\begin{array}{l}\text { Experiment } \\
\text { Method }\end{array}$ & $\begin{array}{l}\text { Background } \\
\text { Gas:Pressure } \\
\text { (host Liquid) }\end{array}$ & Results & Ref. \\
\hline \multirow[t]{3}{*}{$o$-Tolualdehyde } & TDCC & $\begin{array}{l}\text { He: } 800 \text { Torr } \\
\text { (nonane) }\end{array}$ & $\begin{array}{l}E M=290,2.9<S(\text { host })<10.3,1<R<10 \mathrm{drops} / \mathrm{cm}^{2} \mathrm{~s} \\
0.006<1<0.07 \mathrm{~W} / \mathrm{m}^{2},[0 \text {-tolualdehyde }]=100 \mathrm{ppm} \\
1<t_{\mathrm{d}}<10 \mathrm{~s} \text { for } 0.01<1<10 \mathrm{~W} / \mathrm{m}^{2}\end{array}$ & 124 \\
\hline & & $\begin{array}{l}\text { He:800-1450 Torr } \\
\text { (nonane) }\end{array}$ & $\begin{array}{l}220<E W<296, S \text { (host) }=9.03,100<R<1000 \text { counts } / \mathrm{min} \text {, } \\
\text { [o-tolualdehyde] }=1000 \mathrm{ppm} ; E W=240,290,335, \\
\text { le }-4<1<6.0 \mathrm{~W} / \mathrm{m}^{2} \text { for } R \sim 2 \text { drops } / \mathrm{cm}^{2} \mathrm{~s} \text { for } 0.05< \\
{[0 \text {-tolualdehyde] }<1000 \mathrm{ppm}, S(\text { host) }=9.03 ; E W=240,} \\
290,335,1 \mathrm{e}-4<I<0.5 \mathrm{~W} / \mathrm{m}^{2} \text { for } R \sim 2 \text { drops } / \mathrm{cm}^{2} \mathrm{~s} \text { for } 200< \\
<\mathrm{P}_{100}<3000 \text { Torr, } S(\text { host) }=9.65 ; E W=240,290,335 \\
0<t_{\mathrm{d}}<70 \text { s at } P_{\mathrm{tol}}=800,1450 \text { Torr }\end{array}$ & 130 \\
\hline & & $\begin{array}{l}\text { He: } 107,214 \mathrm{kPa} \\
\text { (ethanol, nonane, } \\
n \text {-butylbenzene, } \\
o \text {-xylene) }\end{array}$ & $\begin{array}{l}E W=U V, \text { measurements of PIN decay constants } \\
\text { (for UV on/off) and quenching effects of NO for } \\
\text { values of } P_{\text {tor }}, T \text { and NO concentration }\end{array}$ & 94 \\
\hline \multirow[t]{2}{*}{ Water } & TDCC & He:300-750 Torr & $\begin{array}{l}E W<250,3 \mathrm{e}-8<(T \ln S(\text { host }))^{\wedge}-3<1.6 \mathrm{e}-7,-3<\ln R< \\
4 \mathrm{drops} / \mathrm{cm}^{3} \mathrm{~s} ; 1<\ln R<11 \text { drops } / \mathrm{cm}^{3} \mathrm{~s}, 300<P P(\text { he })<750 \text { Torr }\end{array}$ & 125 \\
\hline & & $\mathrm{O}_{2}: 800$ Torr & $\begin{array}{l}E W=200,1.79<S \text { (host })<3.14,295<T<310 \mathrm{~K}, 1<R \\
<20 \text { drops } / \mathrm{cm}^{2} \mathrm{~s}, 8 \mathrm{e}-6<\mathrm{6}<\mathrm{e}-3 \mathrm{~W} / \mathrm{m}^{2} ; 1<t_{\mathrm{d}}<20 \mathrm{~s} \\
1.79<\mathrm{S} \text { (host) }<3.14,9 \mathrm{e}-6<\mathrm{l}<0.1 \mathrm{~W} / \mathrm{m}^{2}\end{array}$ & 140 \\
\hline Ammonia & $\mathrm{AC}$ & $\begin{array}{l}\text { Air, } \mathrm{Ar} \\
\mathrm{He}, \mathrm{N}_{2}\end{array}$ & $\begin{array}{l}0<\left[\mathrm{SO}_{2}\right]<120 \mathrm{ppm}, 0<R H \%<100, T=\text { ambient, } 40<P N C \\
<8 \mathrm{e}+6 \mathrm{drops} / \mathrm{cm}^{3} \text {, for different carrier gases and six } \\
\text { different ion supplies }\end{array}$ & 102 \\
\hline $\begin{array}{l}\text { Ammonium } \\
\text { chlotide }\end{array}$ & GMRC & $\begin{array}{l}\text { Air and } \mathrm{N}_{2} \text { : } \\
1 \mathrm{~kg} / \mathrm{cm}^{2}\end{array}$ & $\begin{array}{l}{\left[\mathrm{NH}_{3}\right]-[\mathrm{HCl}]=5.9 \mathrm{ppm}, 20<R H \%<90, T=\text { ambient, }} \\
1 \mathrm{e}+3<P N C<1 \mathrm{e}+7 \mathrm{drops} / \mathrm{cm}^{3} ; 6<\left[\mathrm{NH}_{3}\right] \text { and }[\mathrm{HCl}]< \\
20 \mathrm{ppm}, 0<R H \%<80,1 \mathrm{e}+2<P N C<1 \mathrm{e}+8 \mathrm{drops} / \mathrm{cm}^{3} ; \\
6<\left[\mathrm{NH}_{3}\right] \text { and }[\mathrm{HCl}]<19 \mathrm{ppm}, 10<R H \%<40,0.017<(\mathrm{InS})^{\wedge} 2 \\
<0.025,100<P N C<1 \mathrm{e}+8 ; \text { all with and without } \mathrm{PI}-\mathrm{NR} ; \\
\text { NI most effective }\end{array}$ & 85 \\
\hline $\begin{array}{l}\text { CarbonTDCC } \\
\text { tetrachloride }\end{array}$ & & He:1596 Torr & $\begin{array}{l}4<S_{\mathrm{cr}}<5.5,270<T<285 \mathrm{~K}, 1 \mathrm{e}+5<[+ \text { and }- \text { ion }]<1 \mathrm{e}+6 \text { ions } / \mathrm{cm}^{3} \\
\text { generated by alpha particles from Am-241; PI most } \\
\text { effective }\end{array}$ & 82 \\
\hline Chloroform & TDCC & He:1596 Torr & $\begin{array}{l}4.8<S_{\mathrm{cr}}<5.2,260<T<280 \mathrm{~K}, 1 \mathrm{e}+5<[+ \text { and }- \text { ion }]<1 \mathrm{e}+6 \\
\text { ions } / \mathrm{cm}^{3} \text { generated by alpha particles from } \mathrm{Am}-241 \text {; } \\
\text { electric field applied producing } 7<J<30 \mathrm{drops} / \mathrm{cm}^{3} \mathrm{~s} \\
\text { variation for } 1<\text { Efield }<20 \mathrm{~V} / \mathrm{cm}^{3},+ \text { and }- \text { ions effected; } \\
\text { NI most effective }\end{array}$ & 82 \\
\hline \multirow[t]{2}{*}{$\begin{array}{l}\text { Dibutyl } \\
\text { phthalate }\end{array}$} & CFM & $\mathrm{N}_{2}$ & $\begin{array}{l}S=89.9,116,132, R H \%=20,37.5<T<39.8^{\circ} \mathrm{C}, 0<P N C \\
<1150 \text { drops } / \mathrm{cm}^{3}, 1.25 \mathrm{e}+5<[+ \text { and }- \text { ion }]<3.75 \mathrm{e}+5 \text { ions } / \mathrm{cm}^{3} \\
\text { generated by gamma rays from } A m-241\left(100 \mathrm{~m} C_{i}\right) \text { in } \\
\mathrm{H}_{2} \mathrm{O} \text { vapor; } 30<S<175, \mathrm{RH} \%=20 \text { and } 37.6<T<40.2^{\circ} \mathrm{C} \text {, } \\
R H \%=3056.8<T<62.8{ }^{\circ} \mathrm{C}, 0.7<P N C<3000 \mathrm{drops} / \mathrm{cm}^{3} \text {, } \\
R H \%=30 \text { for } 1.25 \mathrm{e}+5<[+ \text { and }- \text { ion }]<3.75 \mathrm{e}+5 \text { ions } / \mathrm{cm}^{3}\end{array}$ & 105 \\
\hline & & & $\begin{array}{l}S=116, \mathrm{RH} \%=20, T=39^{\circ} \mathrm{C}, 0<P N C<300 \mathrm{drops} / \mathrm{cm}^{3}, \\
1.25 \mathrm{e}+5<[+ \text { ion }]<3.75 \mathrm{e}+5 \text { generated by gamma rays } \\
\text { from Am-241; } 90<S<180,37.6<T<40.2^{\circ} \mathrm{C}, 0.7<P N C \\
<2000 \text { drops } / \mathrm{cm}^{3}, 1.25 \mathrm{e}+5<[+ \text { and }- \text { ion }]<3.75 \mathrm{e}+5 \text { ions } / \mathrm{cm} \\
\text { generated by gamma rays from } \mathrm{Am}-241\end{array}$ & 116 \\
\hline Ethanol & TDCC & He:1596 Tort & $\begin{array}{l}1.9<\mathrm{S}_{\mathrm{cr}}<2.3,275<T<300 \mathrm{~K}, 1 \mathrm{e}+5<[+ \text { and }- \text { ions }]<1 \mathrm{e}+5< \\
{[+ \text { and }- \text { ions }]<1 \mathrm{e}+6 \text { ions/cm generated by alpha particles }} \\
\text { from Am-241; PI most effective }\end{array}$ & 82 \\
\hline
\end{tabular}


TABLE 4. Photoinduced and ion-induced nucleation experiments - Continued

\begin{tabular}{|c|c|c|c|c|}
\hline Substance & $\begin{array}{l}\text { Experiment } \\
\text { Method }\end{array}$ & $\begin{array}{l}\text { Background } \\
\text { Gas:Pressure } \\
\text { (host Liquid) }\end{array}$ & Results & Ref. \\
\hline Methanol & TDCC & He:996-1196 Torr & $\begin{array}{l}1.7<S_{\mathrm{cr}}<1.9,255<T<265 \mathrm{~K}, 1 \mathrm{e}+5<[+ \text { and }- \text { ion }]<1 \mathrm{e}+6 \\
\text { alpha particles from Am-241; PI most effective }\end{array}$ & 82 \\
\hline$o$-Xylene & TDCC & He: 1596 Torr & $\begin{array}{l}8<S_{\mathrm{cr}}<13,275<T<300 \mathrm{~K}, 1 \mathrm{e}+5<[+ \text { and }- \text { ions }]<1 \mathrm{e}+6 \mathrm{ions} / \mathrm{cm}^{3} \\
\text { generated by alpha particles from Am-241; PI most } \\
\text { effective }\end{array}$ & 82 \\
\hline \multirow[t]{3}{*}{ Water } & $\mathrm{AC}$ & $\begin{array}{l}\text { Air, Ar, } \\
\mathrm{He}, \mathrm{N}_{2}\end{array}$ & $\begin{array}{l}0<\left[\mathrm{SO}_{2}\right]<120 \mathrm{ppm}, 0<R H \%<100, T=\text { ambient, } 40<P N C \\
<8 \mathrm{e}+6 \text { drops } / \mathrm{cm}^{3} \text {, for different carrier gases and six } \\
\text { different ion supplies }\end{array}$ & 102 \\
\hline & TDCC & He:1596-1642 Torr & $\begin{array}{l}2.75<S_{\mathrm{cr}}<3.5,290<T<315 \mathrm{~K}, 1 \mathrm{e}+5<[+ \text { and }-\mathrm{ion}]<1 \mathrm{e}+6 \\
\text { ion } / \mathrm{cm}^{3} \text { generated by alpha particles from Am-241; NI } \\
\text { most effective }\end{array}$ & 82 \\
\hline & ECC & $\mathrm{Ar}, \mathrm{He}$ & $\begin{array}{l}3.6<S \text { (peak) }<5.6, T \text { initial }=25^{\circ} \mathrm{C}, 0.18<P N C<60 \\
\text { drops } / \mathrm{cm}^{3},[+ \text { and }- \text { ion }]-35 \text { ions } \mathrm{cm}^{3} \text { generated X-ray irradiation }\end{array}$ & 76 \\
\hline
\end{tabular}

Legend

$A C$ : activity (substance specified)

$E W$ : excitation wavelength $(\mathrm{nm})$

$I:$ light intensity (units specified)

$I / I_{0}:$ fraction of incident light

$I_{\mathrm{c}}$ : critical light intensity/power

$J:$ nucleation rate (drops $\left./ \mathrm{cm}^{3} \mathrm{~s}\right)$

$N I$ : negative ion

NR : neutral radical

$P:$ pressure (units specified)

PI : positive ion

PIN : photoinduced nucleation

PNC : particle number concentration (particles $/ \mathrm{cm}^{3}$ )

PP : partial pressure (units and substance specified)

$P_{t a:}:$ total pressure (units specified)

$R:$ photoinduced nucleation rate (units specified)

$R H \%$ : percent relative humidity, water

$S_{\text {G }}$ : cititical supersaturation ratio

$T:$ temperature (units specified)

$t_{\mathrm{r}}:$ irradiation time (units specified)

$t_{\mathrm{d}}:$ photoinduced nucleation delay time (units specified)

UV : ultraviolet

[ ] : concentration (units specified) 
TABLE 5. Experimental devices

\begin{tabular}{lll}
\hline \hline Acronym & Name of the experimental device & Ref. No. \\
\hline AC & Aging Chamber & 102 \\
CFM & Continuous Flow Mixer & 22,161 \\
ECC & Expansion Cloud Chamber & 14,19 \\
EGJ & Expanding Gas Jet & 168 \\
FA & Furnace Apparatus & 79,8 \\
FJ & Free Jet & 32 \\
FR & Flow Reactor & 18,64 \\
GFDC & Gas-Flow Diffusion Chamber (or Flow Chamber & 52,57 \\
& or Laminar Flow Chamber) & \\
GMRC & Gas Mixing Reaction Chamber & 85 \\
KUST & KUST-type apparatus & 144,145 \\
LCJ & Laminar Coaxial Jet & 67 \\
LFAG & Laminar Flow Aerosol Generator & 69 \\
LN & Laval Nozzle & 26 \\
LT (CLT) & Ludwieg Tube and Cryogenic Ludwieg Tube & 148,71 \\
PSM & Particle Size Magnifier & 20,129 \\
SN & Supersonic Nozzle & 44 \\
ST & Shock Tube and Cryogenic Shock Tube & 73,101 \\
IA & Tank Apparatus & 139 \\
TDCC & Thermal Diffusion Cloud Chamber - Upward & 99,94 \\
TDCC & Thermal Diffusion Cloud Chamber - Downward & 77 \\
TGMC & Turbulent Gas Mixing Chamber & 86 \\
IJ & Turbulent Jet & 117 \\
TPEC & Two-Piston Expansion Chamber & 15 \\
\hline
\end{tabular}

\section{Acknowledgment}

The research involved in the preparation of this paper was supported, in part, by National Science Foundation grant No. CTS 8919847.

\section{References}

'Reiss, H. J., J. Chem. Phys. 18, 840 (1950).

${ }^{2}$ Pound, G. M., J. Phys. Chem. Ref. Data 1, 119 (1972).

${ }^{3}$ Hodgson, A. W., Adv. Colloid Interface Sci. 21, 303 (1984).

${ }^{4}$ Heist, R. H., Handbook of Heat and Mass Transfer (Gulf Publishing Co., Houston, 1986). Chapter 14.

${ }^{5}$ (a) Wegener, P. P., and Wu, B. J. C., Adv. Colloid Interface Sci. 7, 325 (1977); (b) Andres, R., Nucleation (Marcel Dekker, Inc., New York, 1969) ed. A. Zettlemoyer, pg. 93; (c) Kaschiev, D., J. Chem. Phys. 76, 5098 (1982).

${ }^{6}$ Katz, J. L., Mirabel, P., Scoppa II, C. J., and Virkler, T. L., J. Chem. Phys. 65, 382 (1976).

${ }^{7}$ Katz, J. L., Scoppa II, C. J., Kumar, N. G., and Mirabel, P., J. Chem. Phys. 62, 448 (1975).

${ }^{8}$ Nuth, J. A., and Donn, B., J. Chem. Phys. 77, 2639 (1982).

${ }^{9}$ Russell, Y. G.; and Heist, R. H., J. Chem. Phys. 69, 3723 (1978).

${ }^{10}$ Martens, J., Uchtmann, H., and Henselm F., J. Phys. Chem. 91, 2489 (1987).

"Hung, C.-H., Kragnopoler, M. J., and Katz, J. L., J. Chem. Phys. 90, 1856 (1983).

${ }^{12}$ Schmitt, J. L., Zalabsky, R. A., and Adams, G. W., J. Chem. Phys. 79, 4496 (1983).

${ }^{13}$ Schmitt, J. L., Adams, G. W., and Zalabsky, R. A., J. Chem. Phys. 77, 2089 (1982).

${ }^{14}$ Adams. G. W.; Schmitt, J. L.; and Zalabsky, R. A., J. Chem. Phys. 81, 5074 (1984).

${ }^{15}$ Strey, R., Wagner, P. E., and Schmeling, T., J. Chem. Phys. 84, 2325 (1986).

${ }^{16}$ Wagner, P. E., and Strey, R., J. Chem. Phys. 80, 5266 (1984).

${ }^{17}$ Peters, F., and Paikert, B., J. Chem. Phys. 91, 5672 (1989).

${ }^{18}$ El-Shall, M. S., Bahta, A., Rabeony, H., and Reiss, H., J. Chem. Phys. 87, 1329 (1987).
${ }^{19}$ Schmitt, J. L., Whitten, J., Adams, G. W., and Zalabsky, R. A., J. Chem. Phys. 92,3693 (1990).

${ }^{20}$ Okuyama, K., Kousaka, Y., Kreidenweis, S., Flagan, R. C., and Seinfeld, J. H., J. Chem. Phys. 89, 6442 (1988).

${ }^{21}$ Kreidenweis, S. M., Flagan, R. C., Seinfeld, J. H., and Okuyama, K., J. Aerosol Sci. 20, 585 (1989).

${ }^{22}$ Wyslouzil, B. E., Seinfeld, J. H., Flagan, R. C., and Okuyama, K., J. Chem. Phys. 94, 6827 (1921).

${ }^{23}$ Flageoliet, C., Cao, M. D., and Mirabel, P., J. Chem. Phys. 72, 544 (1980).

${ }^{24}$ Studzinski, W., Spiegel, G. H., and Zahoransky, R.A., J. Chem. Phys. 84, 4008 (1986).

${ }^{25}$ Becker, C., Reiss, H., and Heist, R. H., J. Chem. Phys. 68, 3585 (1978).

${ }^{26}$ Abraham, O., J. Chem. Phys. 75, 402 (1981).

${ }^{27}$ El-Shall, M. S., Chem. Phys. Lett. 143, 381 (1988).

${ }^{28}$ Smolík, J., and Vítovec, J., Collect. Czech. Chem. Commun. 50, 1349 (1985).

${ }^{29}$ El-Shall, M. S., J. Chem. Phys. 93, 8253 (1989).

${ }^{30}$ Smolik, J., and Vitovec, J., J. Aerosol Sci. 14, 697 (1983).

${ }^{31}$ Wegener, P. P., J. Phys. Chem. 91, 2497 (1987).

${ }^{32}$ Koppenwallner, G., and Dankert, C., J. Phys. Chem. 91, 2482 (1987).

${ }^{33}$ Peters, F., J. Phys. Chem. 91, 2487 (1987).

${ }^{34}$ Heist, R. H., and Reiss, H., J. Chem. Phys. 59, 665 (1973).

${ }^{35}$ Becker, C. J., J. Chem. Phys. 72,4579 (1980).

${ }^{36}$ Mirabcl, P., and Katz, J. L., J. Chcm. Phys. 67,1697 (1977).

${ }^{37}$ Chowdhury, M. A., J. Chem. Phys. 80, 4569 (1984).

${ }^{38}$ Wright, D., Caldwell, R., and El-Shall, M. S., Chem. Phys. Lett. 176, 46 (1991).

${ }^{39}$ Garnier, J. P., and Mirabel, P., Chem. Phys. Lett. 97, 566 (1983).

${ }^{40}$ Warren, D. R., Okuyama, K., Kousaka, Y., Seinfeld, J. H., and Flagan, R. C., J. Colloid Interface Sci. 116, 563 (1987).

${ }^{41}$ Katz, J. L., J. Chem. Phys. 52, 4733 (1970).

${ }^{42}$ Stein, G. D., and Moses, C. A., J. Colloid Interface Sci. 39, 504 (1972).

${ }^{43}$ Wu, B. J. C., Wegener, P. P., and Stein, G. D., J. Chem. Phys. 69, 1776 (1978).

${ }^{44}$ Wu, B. J. C., Wegener, P. P., and Stein, G. D., J. Chem. Phys. 68, 308 (1978).

${ }^{45}$ Stein, G. D., and Armstrong, J. A., J. Chem. Phys. 58, 1999 (1973).

${ }^{46}$ Williams, W. D., and Lewis, J. W., AIAA J. 13, 709 (1975).

${ }^{47}$ El-Shall, M. S., J. Chem. Phys. 90, 6533 (1989). 
${ }^{48}$ Wagner, P. E., and Strey, R., J. Phys. Chem. 85, 2694 (1981).

${ }^{49}$ Heist, R. H., Colling, K. M., and DuPuis, C. S., J. Chem. Phys. 65, 5147 (1976).

${ }^{50}$ Wright, D., and El-Shall, M. S., Chem. Phys. Lett. 189, 103 (1992)

${ }^{51}$ Anisimov, M. P., and Vershinin, S. N., J. Aerosol Sci. 21 (Suppl. 1), S11 (1990).

${ }^{52}$ Anisimov, M. P., and Vershinin, S. N., J. Aerosol Sci. 21 (Suppl. 1), S15 (1990).

${ }^{53}$ Anisimov, M. P., and Taylakov, A. V., J. Aerosol Sci. 21 (Suppl. 1), S19 (1990).

${ }^{54}$ Dankert, C., Rarefied Gas Dyn. 2, 983 (1984).

${ }^{55}$ Picrec, T., Sherman, F. M., and McBride, D. D., Astrunaut. Acta 16, 1 (1971).

${ }^{56}$ Mirabel, P., and Clavelin, J. L., J. Chem. Phys. 68, 5020 (1978).

${ }^{57}$ Anisimov, M. P., and Chervko, A, G., J. Aerosol Sci. 16, 97 (1985).

${ }^{60}$ Miller, R. C., Anderson, R. J., Kassner, J. L., and Hagen, D. E., J. Chem. Phys. 78, 3204 (1983).

${ }^{61}$ Heist, R. H., and Derenthal, J., Lecture Notes in Physics 309, Proceedings of the 12th International Conference on Atmospheric Aerosols and Nucleation, Vienna, August 22-27, 1988.

${ }^{62}$ Tabyashi, K., and Bauer, S. H., Proceedings of the 12th International Symposium in Shock Tubes and Waves, Magness, Jeruslem, 1980.

${ }^{63}$ Kassner Jr., J. L., Plummer, P. L. M., Hale, B. N., and Biermann, A.

H.,Proceedings of International Weather Modification Conference, Canberra, Australia, Sept. 6-13, 1971.

${ }^{64}$ Makela, J., and Hameri, K., J. Aerosol Sci. 21 (Suppl. 1), S677 (1990).

${ }^{65}$ Wegener, P. P., and Lee, C. F., J. Aerosol Sci. 14, 29 (1983).

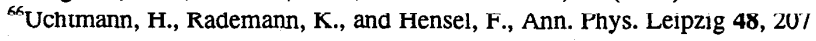
(1991).

${ }^{67}$ Brock, J. R., Kuhn, P. J., and Zehavi, D., J. Aerosol Sci. 19, 413 (1988).

${ }^{68}$ El-Shall, M. S., and Reiss, H., J. Phys. Chem. 92, 1021(1988).

${ }^{69}$ Nguyen, H. V., Okuyama, K., Mimura, T., Kousaka, Y., Flagan, R. C., and Seinfeld, J. H., J. Colloid Interface Sci. 119, 91 (1987).

${ }^{70}$ Stephens, J. R., and Bauer, S. H., Proceedings of the 13th International Symposiumon Shock Tubes and Waves, Edited by Treanor, C. E., and Hall, J. G. (1982).

${ }^{71}$ Zahoransky, R. A., and Wittig, S. L. K., Proceeding of the 13th International Symposium on Shock Tubes and Waves, Edited by Treanor, C. E., and Hall, J. G. (1982).

${ }^{72}$ Mirabel, P. J, and Jaecker-Voirol, A., Lecture Notes in Physics 309, Proceedings of the 12th International Conference on Atmospheric Aerosols and Nucleation, Vienna, August 22-27, 1988.

${ }^{73}$ Peters, F., and Paikert, B., Exp. Fluids 7, 521 (1989).

${ }^{74}$ Wyslouzil, B. E., Seinteld, J. H., Flagan, R. C., and Okuyama, K., J. Chem. Phys. 94, 6842 (1991).

${ }^{75}$ Strey, R., and Wagner, P. E., J. Aerosol Sci. 19, 813 (1988).

${ }^{76}$ White, D. R., and Kassner, J. L., J. Aerosol Sci. 2, 201 (1971).

${ }^{77}$ Smolík, J., and Vítovec, J., Aerosol Sci. Technol. 10, 482 (1989).

${ }^{78}$ Nuth, J. A., and Donn, B., J. Chem. Phys. 78, 1618 (1983).

${ }^{79}$ Nuth, J. A., Donnelly, K. A., Donn, B., and Lilleleht, L. U., J. Chem. Phys. 85, 1116 (1986).

${ }^{80}$ Wen, F. C., McLaughlin, T., and Katz, J. L., Phys. Rev. A 26, 2235 (1982).

${ }^{81}$ Schmitt, J. L., J. Chem. Phys. 89, 5307 (1988).

${ }^{82}$ Rabeony, H., and Mirabel, P., J. Phys. Chem. 91,1815 (1987).

${ }^{83}$ Wen, H. Y., Kasper, G., and Montgomery, D., J. Aerosol Sci. 19, 153 (1988).

${ }^{84}$ Steinwandel, J., Hoschele, J., and Hauser, M., J. Aerosol Sci. 17, 471 (1986).

${ }^{85}$ Banic, C. M., and Iribane, J. V., J. Geophys. Res. 85, 7459 (1980).

${ }^{86}$ Kulmala, M., and Viisanen, Y., J. Aerosol Sci. 19, 825 (1988).

${ }^{87}$ Viisanen, Y., Hillamo, R., Hatakka, J., and Keronen, P., J. Aerosol Sci. 18, 829 (1987).

${ }^{88}$ Steinwandel, J., and Hoeschele, J., J. Chem. Phys. 85, 6765 (1986).

${ }^{89}$ Steinwandel, J., Dietz, Th., Joos, V., and Hauser, M., Ber. Bunsenges. Phys. Chem. 85, 683 (1981).

${ }^{90}$ Gertler, A. W., Berg, J. O., and El-Sayed, M. A., Chem. Phys. Lett. 57, 343 (1978).

${ }^{91}$ Beloded, V. V., Kirichewskij, G. A., and Nuzhnyi, V. M., J. Aerosol Sci. 20, 1043 (1989).
${ }^{92}$ Strey, R., Schmeling, T., and Wagner, P. E., J. Chem. Phys. 85, 6192 (1986).

${ }^{93}$ Chukanov, V. N., and KoroBitsyn, B. A., Russ. J. Phys. Chem. 63, 1085 (1989).

${ }^{94}$ Chen, C.-C., and Katz, J. L., J. Chem. Phys. 88, 5007 (1988).

${ }^{95}$ Katz, J. L., Ruggiero Jr., J. G., Partch, R., Warren, D., and Ebetino, F. H., J. Chem. Phys. 79, 2763 (1983).

${ }^{96}$ Buxbaum, S. P., Haq, Z. U., and Katz, J. L., J. Chem. Phys. 85, 5207 (1986).

${ }^{97}$ Chen, C. C., and Katz, J. L., J. Phys. Chem. 91, 2504 (1987).

${ }^{98}$ Kalisky, O., and Heist, R. H., J. Chem. Phys. 83, 3668 (1985).

${ }^{99}$ Kacker, A., and Heist, R. H., J. Chem. Phys. 82, 2734 (1985).

${ }^{1 m}$ Zahuransky, R. A., J. Chem. Pliys. 82, 2783 (1985).

${ }^{101}$ Steinwandel, J., Ber. Bunsenges. Phys. Chem. 89, 481 (1984).

${ }^{102}$ Diamond, G. L., Iribarne, J. V., and Corr, D. J., J. Aerosol Sci. 16, 43 (1985).

${ }^{103}$ Raes, F., and Janssens, A., J. Aerosol Sci. 16, 217 (1985).

${ }^{104}$ Garnier, J. P., and Mirabel. P., and Migault, B., Chem. Phys. Lett. 115, 101 (1985).

${ }^{105}$ Adachi, M., Okuyama, K., and Seinfeld, J. H., J. Aerosol Sci. 23, 327 (1992).

${ }^{106}$ Garnier, J. P., Mirabel, P., and Rabeony, H., J. Chem. Phys. 79, 2097 (1983).

${ }^{107}$ Zahoransky, R. A., and Peters, F., J. Chem. Phys. 83, 6425 (1985).

${ }^{108}$ Garnier, J. P., and Mirabel, P., J. Chem. Phys. 77, 2035 (1982).

${ }^{109}$ Anisimov, M. P., Vershinin, S. N., Aksenov, A. A., Sgonnov, A.M., and Semin, G. L., Colloid J. USSR 49, 743 (1987).

${ }^{110}$ Mikheev, V. B., Kostrovskii, V. G., Nadolinnyi, V. A., Moralev, V. M., and Kovrigin, V. M., Colloid J. USSK 4Y, 146 (1987).

${ }^{11}$ Barschdorff, D., Dunning, W. J., Wegener, P. P., and Wu, B. J. C., Nat. Phys. Sci. 240, 166 (1972).

${ }^{112}$ Reiss, H., Margolese, D. I., and Schelling, F. J., J. Colloid Interface Sci. 56, 511 (1976).

${ }^{113}$ Jaeger, H. L., Willson, E. J., and Hill, P. G., J. Chem. Phys. 51, 5380 (1969).

${ }^{114}$ Dawson, D. B., Willson, E. J., Hill, P. G., and Russell, K. C., J. Chem. Phys. 51, 5389 (1969).

${ }^{115}$ Peters, F., J. Chem. Phys. 77, 4788 (1982).

${ }^{116}$ Okuyama, K., Adachi, M., Shinagawa, H., Shi, G., and Seinfeld, J. H., J. Aerosol Sci. 22 (Suppl. 1), S85 (1991).

${ }^{117}$ Smolík, J., Koch, W., and Hollander, W., J. Aerosol Sci. 22 (Suppl. 1), S101(1991).

${ }^{118}$ Makela, J., Hameri, K., and Kulmala, M.,J. Aerosol Sci. 22 (Suppl. 1), S89 (1991).

${ }^{119}$ McBride, D. D., Sherman, P. M., and Pierce, T. H., Appl. Sci. Res. 25, 83 (1971).

${ }^{120}$ Strey, R., and Wagner, P. E., J. Phys. Chem. 86, 1013 (1982).

${ }^{121}$ Allen, L. B., and Kassner, J. L., J. Colloid Interface Sci. 30, 81 (1969).

${ }^{122}$ Chen, C.-C., Wen, F. C., and Katz, J. L., J. Chem. Phys. 84, 3843 (1986).

${ }^{123}$ Clavelin, J. L., and Mirabel, P., Chem. Phys. Lett. 65, 327 (1979).

${ }^{124}$ Katz. J. L., Wen, F. C., McLaughlin, T., and Reusch, R. J., Science 196, 1203 (1977).

${ }^{125}$ Reiss, H., Marvin, D. C., and Heist, R. H., J. Colloid Interface Sci. 58, 125 (1977).

${ }^{126}$ Marvin, D. C., and Reiss, H., J. Chem. Phys. 69, 1897 (1978).

${ }^{127}$ Smolík, J., and Vítovec, J., Collect. Czech. Chem. Commun. 43, 2664 (1978).

${ }^{128}$ Agarwal, G., and Heist, R. H., J. Chem. Phys. 73, 902 (1980).

${ }^{129}$ Okuyama, K., Kousaka, Y., Warren, D. R., Flagan, R. C., and Seinfeld, J. H., Aerosol Sci. Technol. 6, 15 (1987).

${ }^{130}$ Katz, J. L., McLaughlin, T., and Wen, F. C., J. Chem. Phys. 75, 1459 (1981).

${ }^{131}$ Kim, S. S., and Stein, G. D., J. Appl. Phys. 51, 6419 (1980).

${ }^{132}$ Wegener, P. P., Clumpner, J. A., and Wu, B. J. C, Phys. Fluids 15, 1869 (1972).

${ }^{133}$ Katz, J. L., and Virkler, T. L., Faraday Discuss. Chem. Soc. 61, 83 (1976). ${ }^{134}$ Wegener, P. P., and Wu, B. J. C., Faraday Discuss. Chem. Soc. 61, 77 (1976).

${ }^{135}$ Schmitt J. L., Rev. Sci. Instrum. 52, 1749 (1981).

${ }^{136}$ Frurip, D. J., and Bauer, S. H., J. Phys. Chem. 81, 1001 (1977).

${ }^{137}$ Barschdorff, D., J. Chem. Phys. 18, 529 (1975). 
${ }^{138}$ Studzinski, W., Zahoransky, R. A., Wittig, S. L. K., and Barschdorff, D., Int. J. Heat Mass Transfer 27, 451 (1984).

${ }^{139}$ Bouland, D., Madelaine, G., Vilga, D., and Bricard, J., J. Chem. Phys. 66, 4854 (1977).

${ }^{140}$ Wen, F. C., McLaughlin, T., and Katz, J. L., Science, 200, 769 (1978). ${ }^{141}$ Flageollet-Daniel, C., Ehrhart, P., and Mirabel, P., J. Chem. Phys. 75, 4615 (1981).

${ }^{142}$ Cordier, B., Papon, P., and Leblond, J., J. Chem. Phys. 74, 3353 (1981).
${ }^{143}$ Cordier, B., and Papon P., Chem. Phys. Lett. 59, 113 (1978).

${ }^{144}$ Rybin, E. N., Pankratova, M. E., and Kogan, Y. I., Russ. J. Phys. Chem. 51, 617 (1977).

${ }^{145}$ Rybin, E. N., Pankratova, M. E., and Kogan, Y. I., Russ. J. Phys. Chem. 50, 452 (1976).

${ }^{146}$ Mirabel, P., and Clavelin, J. L., J. Chem. Phys. 70, 5767 (1979).

${ }^{147}$ Matthew, M. W., and Steinwandel, J. S., J. Aerosol Sci. 14, 755 (1983).

${ }^{148}$ Steinwandel, J., and Buchholz, T., Aerosol Sci. Technol. 3, 71 (1984). 